\title{
Alokasi Air dan Pengembangan Prasarana Penyediaan Air Baku di DAS Ciliman
}

\author{
Isvan Taufik ${ }^{1}$, Muhammad Yanuar J. Purwantoㄹ, Bambang Pramudya ${ }^{2}$, Satyanto K. \\ Saptomo ${ }^{2}$
}

1Program Doktor Sekolah Pascasarjana Institut Pertanian Bogor, e-mail: isvantaufik@gmail.com

${ }^{2}$ Institut Pertanian Bogor, Baranangsiang Bogor Jawa Barat

\begin{abstract}
ABSTRAK
DAS Ciliman merupakan salah satu DAS terbesar kedua di Propinsi Banten dan menjadi bagian dari Wilayah Sungai CilimanCibungur, disamping sebagai lumbung padi di Provinsi Banten, perkembangannya semakin pesat sejak adanya rencana pembangunan Bandara Panimbang, Kawasan Ekonomi Khusus Tanjung Lesung, dan Pembangunan Jalan Tol SerangPanimbang, sehingga perlu diatur alokasi air untuk berbagai kebutuhan dan kemungkinan pengembangan prasarana penyediaan air baku. WEAP merupakan salah satu perangkat lunak hidrologi dalam mengevaluasi dan merencanakan neraca air suatu wilayah. metoda pendekatan WEAP beroperasi dengan prinsip dasar keseimbangan air dan memungkinkan pembuatan skenario berdasarkan kondisi eksisting untuk menyelidiki dampak dari kebijakan atau asumsi alternatif dalam penggunaan dan ketersediaan air dimasa depan. Tujuan penelitian ini, meliputi; (1) Menganalisis potensi ketersediaan air baku pada masing-masing Sub DAS Ciliman, (2) Menganalisis kebutuhan air baku DAS Ciliman, (3). Menganalisis alokasi air untuk setiap kebutuhan air baku pada DAS Ciliman agar terpenuhi dan (4). Menganalisis potensi pengembangan prasarana air baku pada DAS Ciliman. Jenis data yang digunakan dalam penelitian ini adalah data sekunder meliputi: (1) data curah hujan/debit harian, setengah bulanan, dan bulanan dari stasiun pengamatan curah hujan Bendung Ciliman, Gunung Kencana, Bojong Manik dan KP3 Tahun 1998 - 2015, (2) data jumlah penduduk, (3) data jumlah kebutuhan air baku, (4) Data Jaringan Irigasi sekitar DAS Ciliman, (5) peta Sub DAS Ciliman, (6) Alat yang digunakan dalam penelitian ini meliputi unit komputer dan software WEAP. Metode yang digunakan dalam penelitian ini pada dasarnya adalah alokasi air berdasarkan neraca air dan penentuan urutan prioritas kebutuhan. Hasil analisis diperoleh bahwa berdasarkan 5 skenario dengan 3 alternatif pembangunan bendungan yang paling optimal pemanfaatan airnya adalah skenario 5 dengan pengembangan luas areal pertanian sebesar 3.200 ha dan potensi pembangkitan tenaga listrik rata-rata sebesar $0.96 \mathrm{MW}$ dalam setahun.
\end{abstract}

Kata kunci: Ketersediaan air, Kebutuhan air, Neraca air, Alokasi air, DAS Ciliman

\begin{abstract}
Ciliman Watershed is one of the second largest watersheds in Banten Province and is part of the Ciliman-Cibungur River Region, besides being a rice barn in Banten Province, its development has accelerated since the development of Panimbang Airport, Tanjung Lesung Special Economic Zone, and Serang Toll Road Development -Considering. Therefore, it is necessary to regulate the water allocation for various needs and the possibility of developing water supply infrastructure. WEAP is one of the hydrological software in evaluating and planning the water balance of a region. The WEAP approach method operates with the basic principle of water balance and allows the creation of scenarios based on existing conditions to investigate the impact of policies or alternative assumptions in the use and availability of water in the future.The purpose of this study includes; (1) Analyzing the potential availability of raw water in each Ciliman Sub-watershed, (2) Analyzing the raw water needs of the Ciliman watershed, (3). Analyzing water allocation for each raw water requirement in the Ciliman watershed to be fulfilled and (4). Analyzing the potential for developing raw water infrastructure in the Ciliman watershed. The types of data used in this study are secondary data including: (1) monthly rainfall data from the Ciliman reservoir rainfall observation station, Gunung Kencana, Bojong Manik and KP3 at year 1998 - 2015, (2) population data of Ciliman watershed region, (3) the amount of raw water needs data, (4) Irrigation networks around the Ciliman watershed data (5) maps of the Ciliman watershed, (6) Tools used in this study include computer units and WEAP software. The method used in this study basically is the water allocation based on the water balance and determining the order of priority needs. The results analysis obtained that based on 5 scenarios with 3 alternative dam construction the most optimal use of water is fifth scenario with the development of an agricultural area of 3,200 ha and an average electricity generation potential of $0.96 \mathrm{MW}$ in a year.
\end{abstract}

Keywords: Water availability, Water requirements, Water balance, Water allocation, Ciliman watershed

Citation: Taufik, I., Purwanto, M. Y. J., Pramudya, B., dan Saptomo, S. K. (2020). Alokasi Air dan Pengembangan Prasarana Penyediaan Air Baku di DAS Ciliman. Jurnal Ilmu Lingkungan, 18(1),171-184, doi:10.14710/jil.18.1.171-184 
Taufik, I., Purwanto, M. Y. J., Pramudya, B., dan Saptomo, S. K. (2020). Alokasi Air dan Pengembangan Prasarana Penyediaan Air Baku di DAS Ciliman. Jurnal IImu Lingkungan, 18(1),171-184, doi:10.14710/jil.18.1.171-184

\section{Latar Belakang}

Alokasi Air merupakan suatu kegiatan pengaturan pemberian air dalam jumlah volume/kuantitas dan waktu tertentu yang didasarkan atas ketersediaan dan kebutuhan air menurut jenis, volume dan waktu tertentu yang disesuaikan dengan hasil kesepakatan urutan prioritasnya. Di Indonesia, jumlah potensi air yang tersedia sebanyak 3,221 Milyar $\mathrm{m}^{3} /$ tahun atau dapat memenuhi kebutuhan air masyarakat dengan kapasitas 16.000 meter kubik perkapita/tahun (Departemen Pekerjaan Umum, Tahun 2015). Dari angka ini, potensi ketersediaan air ini sebenarnya mencukupi bila dilihat dari kebutuhan rata-rata, tapi permasalahannya dilihat ketersediaannya tidak merata di setiap wilayah dan waktu, Pulau Kalimantan dan Papua memiliki ketersediaan air paling tinggi dibanding dengan pulau-pulau lainnya di Indonesia yaitu sebesar 30\%, Pulau Sumatera sebanyak 22\%, Pulau Sulawesi sebanyak 9\%, sedangkan Pulau Jawa yang luasnya hanya tujuh persen dari luas daratan Indonesia, harus melayani kebutuhan air untuk $65 \%$ jumlah penduduk, padahal potensi airnya hanya $4,5 \%$ (Hatmoko et al, 2012).

Berdasarkan perhitungan kebutuhan air di Pulau-pulau di Indonesia pada tahun 2010, kebutuhan air terbesar adalah di Pulau Jawa yaitu sebesar $2.079 \mathrm{~m}^{3} /$ detik. Kebutuhan air tersebut meliputi $12 \%$ kebutuhan air RKI $\left(240 \mathrm{~m}^{3} /\right.$ detik $)$ dan $88 \%$ kebutuhan air irigasi $\left(1.838 \mathrm{~m}^{3} /\right.$ detik), namun yang menjadi isu permasalahan antara lain sebanyak $46 \%$ areal irigasi kondisinya rusak, tampungan air perkapita hanya sebesar $50 \mathrm{~m}^{3} / \mathrm{kapita}$, frekuensi kejadian banjir di kota-kota besar masih tinggi, kapasitas air baku hingga $2014\left(51,44 \mathrm{~m}^{3} /\right.$ detik $)$ baru menjangkau layanan $\pm 66,35 \%$ penduduk. Dilihat dari neraca air Pulau Jawa, pada umumnya wilayah-wilayah sungai di Pulau Jawa berada pada zona kritis (Hatmoko et al, 2012), namun untuk wilayah sungai di Provinsi Banten, berdasarkan hasil perhitungan indeks ketersediaan air perkapita diperoleh hasil bahwa pada bulan Juni hingga September, jumlah ketersediaan air semakin menurun mendekati jumlah kebutuhan air.

DAS Ciliman merupakan DAS terbesar kedua dan menjadi bagian dari Wilayah Sungai CilimanCibungur, memiliki potensi Sumberdaya Air yang sangat strategis yang salah satunya dimanfaatkan untuk mengairi Daerah Irigasi Ciliman seluas 5.423 Ha yang merupakan salah satu lahan sawah beririgasi teknis yang terbesar di Kabupaten Pandeglang dan penyumbang lumbung padi nasional. Selain itu, pada DAS ini juga dimanfaatkan untuk pengembangan Kawasan Ekonomi Khusus Tanjung Lesung, Pembangunan Bandara Panimbang dan Jalan Tol Serang-Panimbang. Pembangunan di sepanjang DAS Ciliman yang sangat pesat, menjadikan sungai ini sangat rawan akan bencana banjir. Beberapa penelitian telah dilakukan pada DAS Ciliman, diantaranya yaitu Dinas Sumber Daya Air dan Permukiman (2014) melakukan kajian melalui paket pekerjaan DED Penyediaan Air bAku Kawasan Tanjung Lesung, Dinas Sumber Daya Air dan Permukiman (2015) Studi Komprehensif Pengendalian Daya Rusak Air pada DAS Ciliman, Dinas Sumber Daya Air dan Permukiman (2016) Penyusunan Perencanaan dan Evaluasi Alokasi Air Pada DAS Ciliman, Dirjen Cipta Karya Kementerian PUPR (2016) Perencanaan Pengembangan SPAM Mendukung Kawasan Strategis Pariwisata Nasional Wilayah Barat, Dinas Pekerjaan Umum dan Penataan Ruang (2017-2018) Pra FS dan FS Pembangunan Multipurpose DAM pada DAS Ciliman, Mubarok (2018) melakukan penelitian tentang Perencanaan Bendungan Ciliman di Kabupaten Lebak, Banten. Sedangkan penelitian lain mengenai Alokasi Air dan Pengembangan Prasarana Penyediaan Air Baku diantaranya Hussein (2015) yang melakukan penelitian tentang pemodelan sistem sumber daya air untuk alokasi air yang efektif di Cekungan Juba, Somalia Selatan. Berdasarkan data neraca air yang tercatat pada Bendung Ciliman Tahun 2017/2018 terlihat sangat kontras pada Musim Tanam I (November-April) terdapat deviasi $20,71 \mathrm{~m}^{3} /$ detik, sementara pada saat Musim Tanam II (MeiSeptember) defisit airnya sebesar $1,89 \mathrm{~m}^{3} /$ detik serta pencatatan debit di pos pengamatan Munjul pada Bulan Januari 2005, Q Sungai Ciliman sebesar 16,9 $\mathrm{m}^{3}$ /detik, namun pada Bulan Januari 2013, Q Sungai Ciliman meningkat menjadi $41,7 \mathrm{~m}^{3} /$ detik. Dari kedua hal tersebut, artinya diperlukan upaya konservasi dan penampungan air baku pada musim penghujan agar hujan yang turun dapat ditampung dan diserap kedalam tanah. Jika diasumsikan jumlah ketersediaan air adalah tetap sementara jumlah kebutuhan air diproyeksikan semakin meningkat setiap tahunnya akibat pertumbuhan populasi penduduk, maka diperlukan upaya khusus untuk mengatasi kondisi tersebut diantaranya pengembangan insfrastruktur berupa bendungan guna meminimalisir dampak banjir sekaligus sebagai infrastruktur penyedia air baku.

\section{Metodologi}

\subsection{Jenis dan sumber data}

Jenis data yang digunakan dalam kajian ini adalah data sekunder yang meliputi: (1) data curah hujan/debit harian, setengah bulanan, dan bulanan dari 4 stasiun pengamatan curah hujan Tahun 1998 2015, yaitu stasiun pengamatan curah hujan Bendung Ciliman, Gunung Kencana, Bojong Manik, dan KP3, (2) data jumlah penduduk, (3) data jumlah kebutuhan air baku, (4) Data Jaringan Irigasi sekitar DAS Ciliman, (5) peta Sub DAS Ciliman, (6) Alat yang digunakan dalam penelitian ini meliputi unit komputer dan software WEAP. 


\subsection{Metode pengumpulan data}

Metode pengumpulan data diperoleh lewat pengumpulan data sekunder dari beberapa instansi terkait, diantaranya dari Stasiun BMKG Taktakan Serang, Dinas PUPR Provinsi Banten, BBWS Cidanau Ciujung Cidurian Kementerian PUPR, BPS Kabupaten Pandeglang, dan BPS Kabupaten Lebak.

\subsection{Metode analisis data}

WEAP bertujuan untuk memasukkan isuisu/permasalahan pada DAS menjadi alat praktis namun kuat untuk sumber daya air terpadu dalam perencanaan. WEAP merupakan salah satu perangkat lunak hidrologi dalam mengevaluasi dan merencanakan neraca air suatu wilayah. Program ini sangat mudah dan fleksibel untuk digunakan serta memberikan informasi yang mudah bagi para stakeholder di bidang sumber daya air. Atribut yang diperlukan dalam program ini merupakan atribut hidrologi serta bentuk data dalam shape file. Output dari program ini merupakan suatu skema perencanaan neraca air, dimana dari data yang dihimpun akan diketahui kekurangan dan kelebihan air dari suatu wilayah serta perlu tidaknya dibangun suatu waduk/tampungan air untuk merancang kebutuhan air dalam suatu wilayah. Pada dasarnya, metoda pendekatan WEAP beroperasi dengan prinsip dasar water balance, WEAP dapat diaplikasikan untuk sistem pengairan pada wilayah pertanian dan perkotaan, sebuah daerah tangkapan air, atau kondisi sungai yang melewati beberapa batas wilayah yang rumit. Lebih dari itu, WEAP dapat memetakan permasalahan yang luas, seperti analisa kebutuhan sektoral, konservasi air, prioritas neraca air, simulasi stream flow dan ground water, pengoperasian waduk, pembangkit tenaga air, jalur polusi, keadaan ekosistem yang seharusnya, penilaian terhadap kondisi kritis, dan merancang analisa keuangan dari pekerjaan.

Seseorang yang menganalisa dengan menggunakan WEAP dapat menghadirkan sistem mengenai berbagai sumber persediaan air (seperti : sungai, teluk, air tanah, waduk, tanaman); pengambilan air, pengiriman air dan fasilitas drainase, kondisi ekosistem yang seharusnya, pertumbuhan polusi dan kebutuhan air. Struktur data dan tingkat keakurasian data yang dimasukan secara otomatis dapat menentukan tingkat ketelitian analisis, berdasarkan ketersediaan data yang ada. Aplikasi WEAP secara umum meliputi beberapa langkah. 1). Definisi studi mengatur batasan waktu, batas wilayah, bentuk dan komponen dari masalah yang dianalisa. 2). Kondisi eksisting, yang dapat dilihat sebagai langkah gabungan dalam pengembangan aplikasi, menyediakan gambaran mengenai kebutuhan air aktual, beban polusi, sumber dan ketersediaan air pada sistem. 3). Asumsi utama dapat dibuat didalam kondisi eksisting untuk 173 merepresentasikan kebijakan, keuangan dan faktor yang mempengaruhi permintaan, polusi, ketersediaan air dan kondisi hidrologi. 4). Pembuatan skenario berdasarkan kondisi eksisting untuk menyelidiki dampak dari kebijakan atau asumsi alternatif dalam penggunaan dan ketersediaan air dimasa depan. 5). Evaluasi skenario melalui kecukupan air, manfaat dan biaya yang dikeluarkan, keselarasan dengan kondisi lingkungan, dan kepekaan ketidak-pastian di variabel kunci. Adapun metodologi WEAP secara diagramatis dapat dilihat pada Gambar 1.

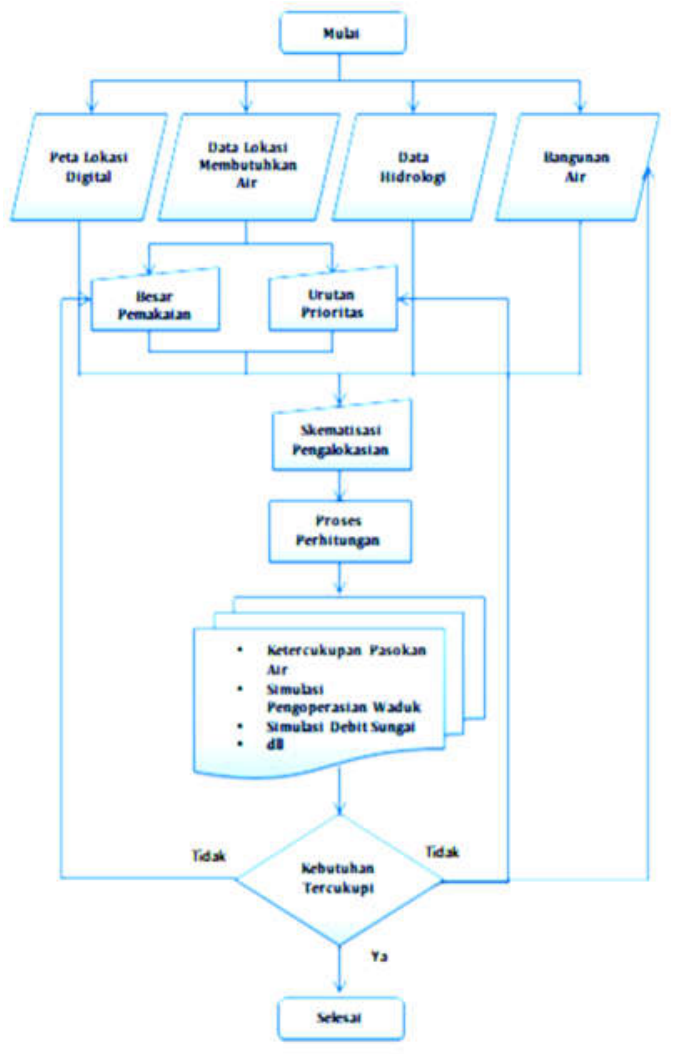

Gambar 1 Diagram Alur WEAP

\section{Hasil dan Pembahasan}

\subsection{Neraca Air}

Alokasi sumber daya air yang terbatas, untuk penggunaan pertanian, kota dan lingkungan memerlukan evaluasi yang terintegrasi penuh dalam pasokan air, kualitas, permintaan, air dan pertimbangan ekologi. Evaluasi Air dan sistem Perencanaan, atau WEAP, bertujuan untuk mengevaluasi pemenuhan kebutuhan air terutama terkait dengan isu strategis kawasan, antara lain Kawasan Ekonomi Khusus Tanjung Lesung dan rencana Bandara Panimbang. Neraca air dianalisis dengan menggunakan bantuan perangkat lunak WEAP sehingga diharapkan mendapatkan hasil yang lebih teliti/akurat. Simulasi ini memperhitungkan kebutuhan air baku, air irigasi, dan kebutuhan air bandara serta KEK Tanjung Lesung. Suplai air yang masuk ke Sungai Ciliman diperhitungkan dari masing-masing sub DAS utama, dengan hujan yang 
menjadi acuan Q80. Adapun Neraca air pada DAS Ciliman dapat dilihat pada Gambar 2.

\subsection{Skematisasi Neraca Air}

Untuk dapat mensimulasikan satuan wilayah sungai sebagai suatu sistem tata air, maka disusun skematisasi sistem tata air yang dapat menggambarkan sistem tata air secara hidrologis. Skematisasi sistem tata air terdiri atas simpul-simpul yang menyatakan sumber air, kebutuhan air dan infrastruktur. Simpul-simpul tersebut terdiri atas tiga jenis, yaitu simpul biasa, simpul aktivitas, dan simpul kendali sebagai berikut :

\section{Ciliman Watershed Water Balance}

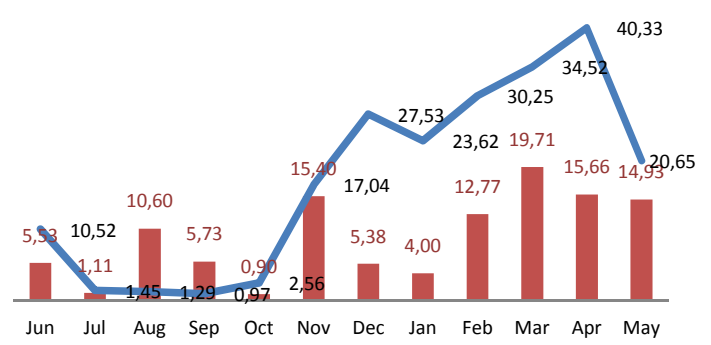

Gambar 2 Neraca Air DAS Ciliman

1 Simpul biasa merupakan unsur dalam tata air yang tidak mengatur aliran air. Simpulsimpul ini dapat berupa Simpul Aliran (inflow node); Simpul Akhir (terminal node); Simpul Pertemuan (confluence node); Simpul Listrik Mikrohidro (run-of-river node); Simpul Semu (dummy node); dan Simpul Drainase SubWilayah Sungai (district drainage node);

2 Simpul aktivitas yang merupakan simpul kebutuhan air, dan dapat berupa : Simpul Air Bersih (public water supply node); Simpul Aliran Rendah (low flow node); Simpul Irigasi (irrigation node); Simpul Tambak (fishpond node); Simpul Penyadapan Air untuk SubWilayah Sungai (district extraction node); dan Simpul Kehilangan Air (loss flow).

3 Simpul kendali merupakan infrastruktur pengairan yang dapat digunakan untuk mengendalikan sistem tata air, dapat berupa: waduk dan bendung.

\subsection{Water District}

Untuk dapat menggambarkan skematisasi dengan baik, maka biasa dilakukan deliniasi DAS atas beberapa sub DAS, atau water district. Sub-DAS atau Water District merupakan suatu satuan luasan alami terkecil, dengan batas potongan berupa infrastruktur di sungai atau batas alami berupa anak atau cabang sungai, yang selanjutnya digunakan untuk penggambaran daerah studi dalam bentuk Skematisasi. Sub-DAS ini mencirikan :

- unit hidrologi terkecil yang mencakupi kebutuhan air dan pasokan air

- mempunyai persamaan sifat dalam merespon hujan dan aliran

- unit yang saling melengkapi dalam pengaturan sumber daya air dan dapat dimungkinkan untuk membuat keseimbangan

Ukuran dari pembagian sub-DAS banyak pertimbangannya, tergantung pada detil wilayah dari analisa kebutuhan dan pasokan dan lokasi pada bangunan utama pada sungai. Batas dari sub-DAS pada suatu DAS bagian hilir biasanya bertepatan dengan batas dari DAS Pada bagian tengah dari DAS dan kondisinya lebih kompleks dengan adanya bangunan-bangunan air seperti bendung, waduk, sistem saluran utama dll.Masing-masing sub DAS ini mempunyai karakteristik tertentu yang secara umum dapat digolongkan atas tiga bagian, yaitu sub-DAS di hulu, tengah dan hilir. Sub-DAS di bagian hulu, merupakan daerah tangkapan air. Pada kawasan ini perlu diberikan perlindungan konservasi lahan, penampungan air dan pengendalian anak - anak sungai. Pemodelan pada kawasan yang menjadi simpul inflow ini menyangkut kalibrasi hubungan hujan-limpasan. Pada sub DAS di bagian tengah lebih kompleks, sebab merupakan daerah produksi dan pemanfaatan; dicirikan dengan adanya pertanian, kebutuhan air baku, dan sebagainya. Sub-DAS di daerah hilir merupakan daerah pemanfaatan dan juga pembuangan; dapat berupa daerah irigasi teknis, tambak, dan perkotaan dengan permasalahan alokasi air, pengendalian muara pantai, dan intrusi air laut.

\subsection{Metoda Perhitungan Neraca Air}

Perhitungan neraca air DAS Ciliman dihitung dengan metode DSS-WEAP, yaitu : dengan memberikan input data yang kompleks dari fluktuasi ketersediaan dan kebutuhan air pada setiap lokasi pada sistem tata air yang ada yang di dapat dari hasil inventarisasi data. Kemudian dari hasil perhitungan dari metode tersebut akan dibuat analisanya.

\subsection{Skematisasi Water Suply dan Demand}

Decision Support Sistem (DSS) - Sistem Pendukung Pengambilan Keputusan untuk Pola Pengelolaan wilayah sungai. DSS dipergunakan dalam kerangka kerja untuk merumuskan, menganalisa berbagai alternatif strategi pengelolaan sumber daya air dan menentukan efek dari strategi. DSS-WEAP merupakan salah satu software sistem pendukung Pengambilan Keputusan di dalam proses perencanaan sumberdaya air wilayah sungai. DSSWEAP itu sendiri adalah paket model generik untuk simulasi perilaku satu atau lebih DAS dalam berbagai 
kondisi hidrologi, kebutuhan air, serta struktur yang ada dan yang direncanakan. Model ini merupakan alat simulasi yang komprehensif, terpadu dan fleksibel yang menghubungkan masukkan hidrologi berupa ketersediaan air di berbagai lokasi pada beragam aktivitas pemakaian air. Pada proses perhitungan neraca air dengan menggunakan DSSWEAP DAS Ciliman dibagi atas 24 sub DAS atau water district, dapat dilihat pada Gambar 3 berikut ini.

\subsection{Input Data dalam WEAP \\ A. Input Data Debit Sungai}

Input untuk debit sungai merupakan hasil dari analisa debit berdasarkan masukan data Curah Hujan tahun 1998-2015 dan evapotranspirasi potensial bulanan, kelembaban tanah (soil moisture) dan tampungan air tanah menggunakan metode Mock. Dalam simulasi menggunakan aplikasi WEAP, input data yang digunakan adalah sebagaimana terlihat pada Gambar 4.

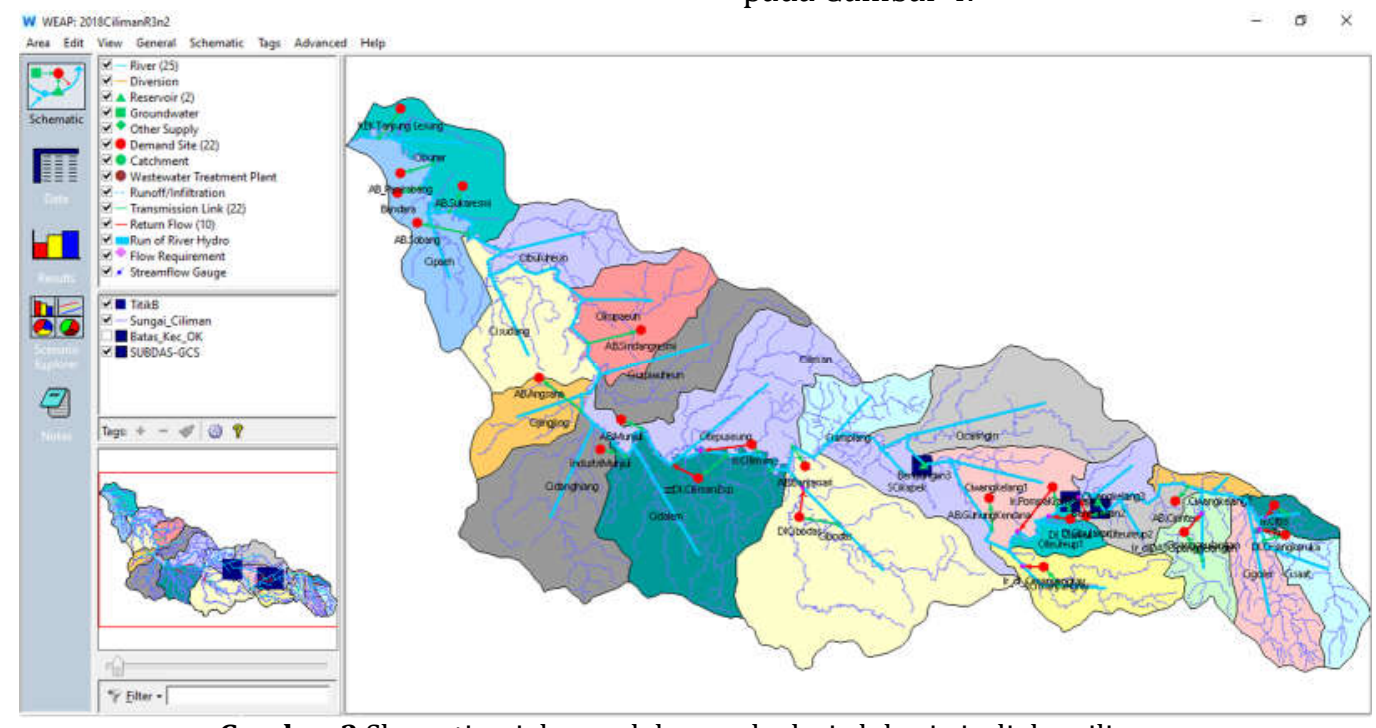

Gambar 3 Skematisasi demand dan suply dari alokasi air di das ciliman

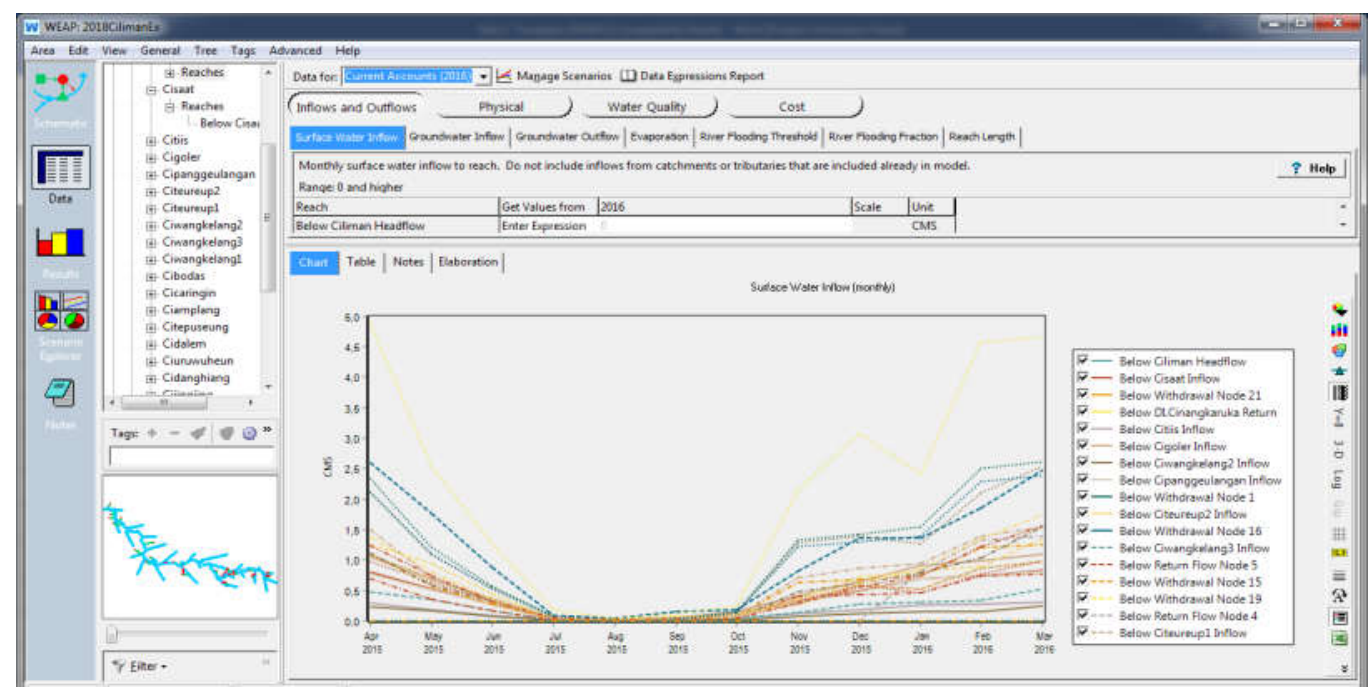

Gambar 4 Input Debit Andalan Per Sub Das Ciliman Tahun 1998-2016

\section{B. Input Data Kebutuhan Air Irigasi}

Kebutuhan air irigasi yang diperhitungkan pada simulasi ini mengacu pada rekomendasi hasil analisis yaitu pola tanam 1 . Besar kebutuhan air irigasi dengan pola tanam ini adalah 6.73 liter/detik/hektar atau setara dengan 212,237.21 m3/tahun/hektar. Air irigasi ini kembali ke sistem sungai namun tidak seluruhnya (return flow), dengan pertimbangan konsumsi air oleh tanaman, efisiensi saluran, sulitnya identifikasi outlet dari saluran-saluran pembuang yang terkadang berada di sungai yang berbeda dengan sungai di mana bendung berada, dan faktor-faktor lainnya maka air yang kembali ke sistem sungai diperhitungkan maksimum $20 \%$ dari suplai (yang dikonsumsi oleh daerah irigasi 80\% dari suplai). Input lainnya adalah berupa luas Daerah Irigasi yang akan dilayani.Data kebutuhan air irigasi diambil dari hasil perhitungan kebutuhan air irigasi untuk setiap bulannya dalam satuan lt/dt/ha. 
- Luas irigasi citiis dan cinangkaruka masingmasing yaitu 70 hektar dengan kebutuhan air per tahun sebesar $30.960 \mathrm{~m}^{3} / \mathrm{ha}$. Prioritas pemenuhan kebutuhan airnya yaitu prioritas pertama.

- Irigasi cipanggelangan seluas 335 hektar dengan kebutuhan air per tahun sebesar $30.960 \mathrm{~m}^{3} /$ ha. Pengaruh pos hujan yang sama (PCH Bojong Manik) Prioritas pemenuhan kebutuhan airnya yaitu prioritas pertama.

- Irigasi cimanyangray seluas 195 hektar dengan kebutuhan air per tahun sebesar $33.937 \mathrm{~m} 3 / \mathrm{ha}$. Prioritas pemenuhan kebutuhan airnya yaitu prioritas pertama.

- Irigasi cibodas seluas 100 hektar dengan kebutuhan air per tahun sebesar 30.960 m3/ha. Prioritas pemenuhan kebutuhan airnya yaitu prioritas pertama.

- Irigasi cilimus seluas 80 hektar dengan kebutuhan air per tahun sebesar 29.842 m3/ha. Prioritas pemenuhan kebutuhan airnya yaitu prioritas pertama.

- Irigasi cibulakan seluas 80 hektar dengan kebutuhan air per tahun sebesar 33.219 m3/ha. Prioritas pemenuhan kebutuhan airnya yaitu prioritas pertama.

- Irigasi pompa kramat jaya seluas 108 hektar dengan kebutuhan air per tahun sebesar $29.842 \mathrm{~m}^{3} / \mathrm{ha}$. Prioritas pemenuhan kebutuhan airnya yaitu prioritas ketiga.
- Untuk irigasi ciliman seluas 5.423 hektar dengan kebutuhan air per tahun sebesar $39.084 \mathrm{~m} 3 / \mathrm{ha}$. Prioritas pemenuhan kebutuhan airnya yaitu prioritas ketiga.

Selengkapnya mengenai kebutuhan air irigasi dapat dilihat pada Gambar 5 berikut.

\section{Input Data Kebutuhan Air Penduduk}

Untuk air baku penduduk, inputnya adalah jumlah penduduk dengan kebutuhan dasar domestik adalah $120 \mathrm{lt} / \mathrm{jiwa} / \mathrm{hr}$ atau 43.20 $\mathrm{m}^{3}$ /orang/tahun (Pedoman Penentuan Kebutuhan Air Baku untuk rumah tangga, perkotaan dan industri, Departemen Pemukiman dan Prasarana Wilayah Tahun 2003 dan SNI tahun 2002). Berikut ini input kebutuhan air baku penduduk pada DAS Ciliman, dengan jumlah penduduk pada tahun 2016 adalah 342.606 jiwa terdiri dari 3 Kecamatan di Kabupaten Lebak (Kecamatan Banjarsari, Cirinten, dan Gunung Kencana), dan 6 Kecamatan di Kabupaten Pandeglang (Kecamatan Angsana, Munjul, Panimbang, Sindangresmi, Sobang, dan Sukaresmi). Prioritas pemenuhan kebutuhan air untuk air baku Panimbang dan Sukaresmi adalah prioritas keempat, sedangkan sisanya adalah prioritas kedua.

Untuk proyeksi pertumbuhan penduduk juga sudah dimasukan dalam skenario untuk tahun 2017-2036 dengan laju pertumbuhan penduduk di Kabupaten Lebak sebesar $0,83 \%$ dan laju pertumbuhan penduduk di Kabupaten Pandeglang sebesar 1,30\%, dan konsumsi air per kapita diasumsikan sebesar 120 liter/hari, atau sama dengan $43.8 \mathrm{~m}^{3} /$ tahun, sehingga data proyeksi sampai tahun 2036 dapat dilihat pada Gambar 6 dan Gambar 7.

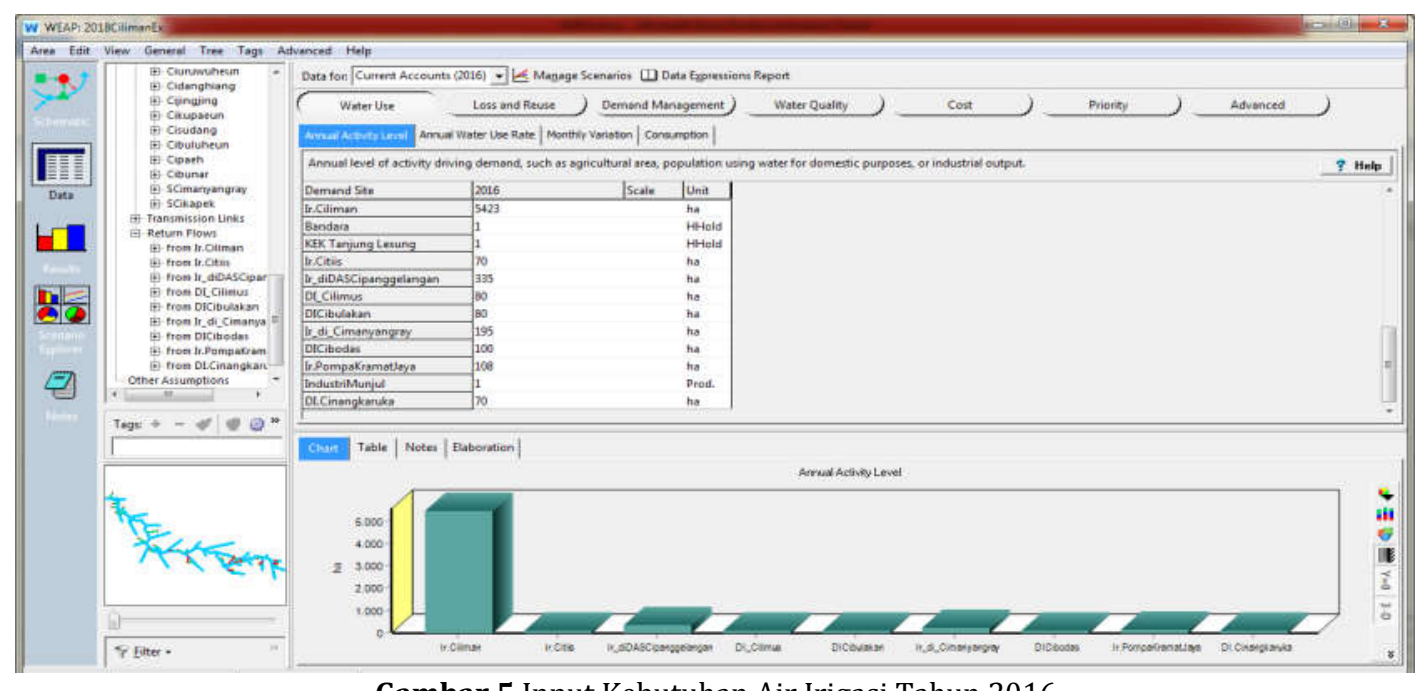

Gambar 5 Input Kebutuhan Air Irigasi Tahun 2016 


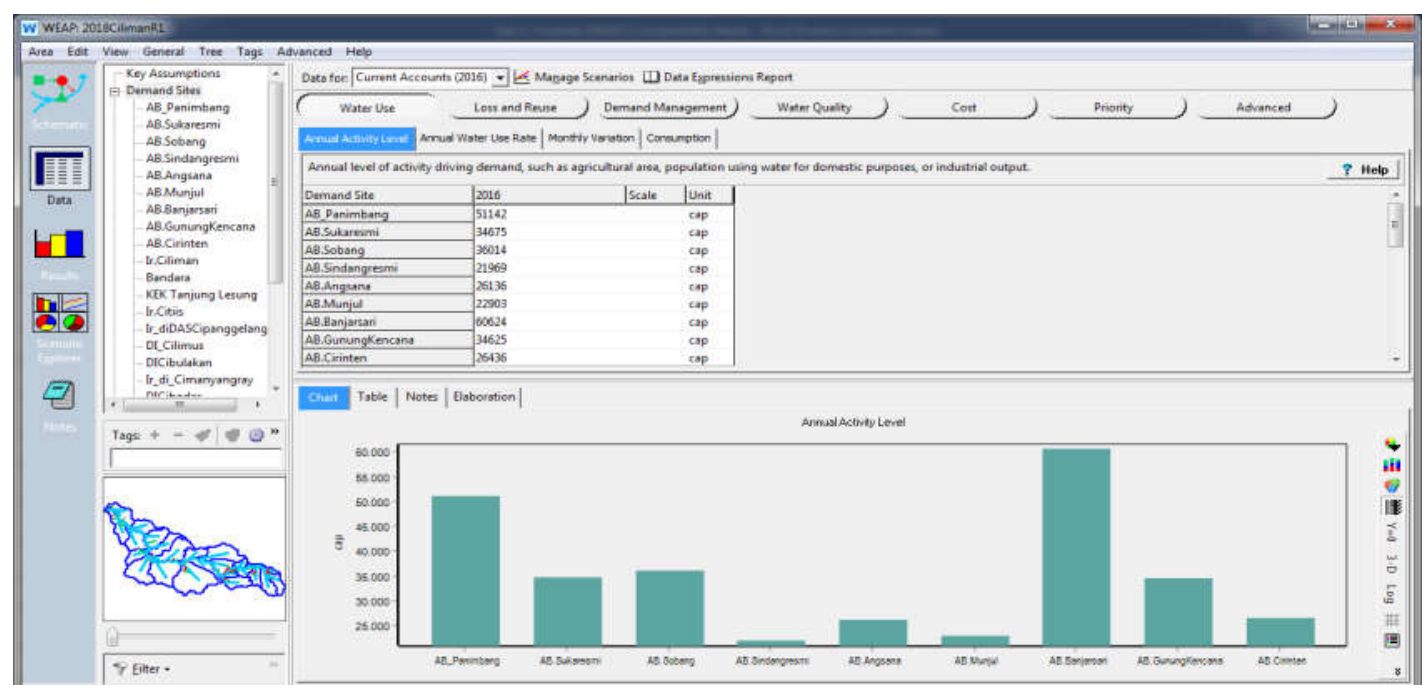

Gambar 6 Input kebutuhan air baku

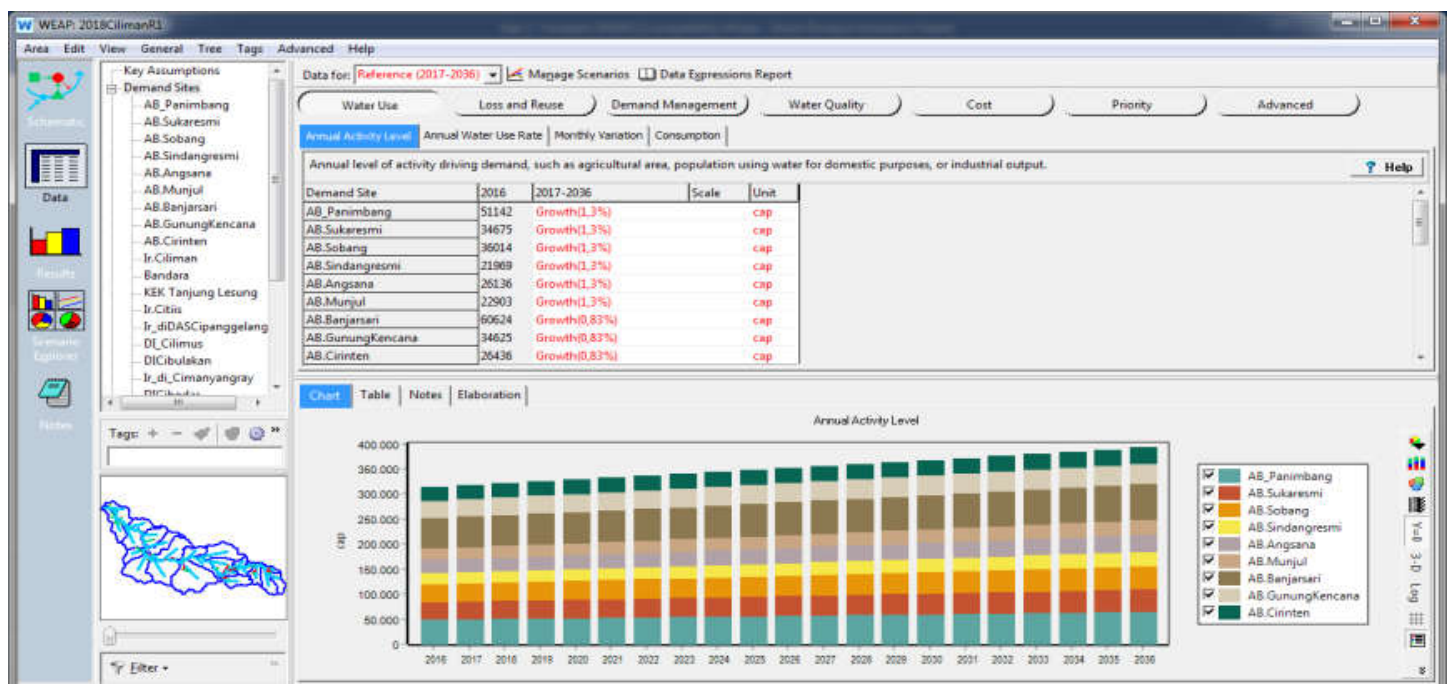

Gambar 7 Input kebutuhan air baku setelah proyeksi

\section{Input Data Kebutuhan Air Industri}

Untuk air baku Industri, diasumsikan kebutuhan industri adalah menengah (Kriteria Perencanaan Ditjen Cipta Karya Dinas PU, 1996). Berdasarkan proyeksi kebutuhan air industri pada DAS Ciliman, diketahui bahwa pada DAS Ciliman terdapat dua industri kategori sedang dengan ratarata konsumsi kebutuhan air 1.000 liter/unit/hari atau sama dengan $365,25 \mathrm{~m} 3 /$ tahun/unit. Kebutuhan air ini tumbuh tiap tahun sebesar 5\%, sehingga pada tahun akhir proyeksi (2036) kebutuhan air baku industri pada Kecamatan Munjul sebesar 0,000041 m3/detik. Prioritas pemenuhan kebutuhan air untuk Industri Munjul adalah Prioritas keempat. Diasumsikan sampai pada tahun 2016 tidak mengalami penambahan jumlah industri.

\section{E. Bandara dan KEK Tanjung Lesung}

Kebutuhan air Bandara dan KEK Tanjung Lesung dianggap tetap (tidak tumbuh). Besar Kebutuhan air untuk Bandara adalah $12.1 \mathrm{lt} /$ detik atau sama dengan $381.585,6 \mathrm{~m} 3$ per tahun dan KEK Tanjung Lesung sebersar $400 \mathrm{lt} /$ detik atau sama dengan 12.614.400 m3 per tahun. Prioritas pemenuhan kebutuhan air untuk bandara dan KEK tanjung lesung adalah Prioritas kelima.

\subsection{Hasil Perhitungan Neraca Air dengan DSS- WEAP}

Berdasarkan hasil perhitungan neraca air menggunakan DSS WEAP, proses pengambilan air terjadi pada sub DAS sebagai berikut

\section{A. Sub DAS Citiis}

Kebutuhan air yang termasuk pada Sub DAS Citiis adalah : Irigasi Citiis.

\section{B. Sub DAS Cipanggelangan}

Kebutuhan air yang termasuk pada Sub DAS Cipanggelangan adalah : Irigasi Cipanggelangan.

\section{Sub DAS Cimanyangray}

Kebutuhan air yang termasuk pada Sub DAS Cimanyangray adalah : Irigasi Cimanyangray.

\section{Sub DAS Cibodas}

Kebutuhan air yang termasuk pada Sub DAS Cibodas adalah : Irigasi Cibodas.

\section{E. DAS Ciliman}


Kebutuhan air yang mengambil langsung air dari sungai utama ciliman yaitu Irigasi Cinangkaruka, Air Baku Cirinten, Irigasi Cibulakan, Irigasi Cilimus, Irigasi Pompa Kramatjaya, Air Baku Gunung Kencana, Air Baku Banjarsari, Irigasi Ciliman, Air Baku Munjul, Industri Munjul, Air Baku Angsana, Air Baku Sindangresmi, Air Baku Sobang, Air Baku Sukaresmi, Bandara, Air Baku Panimbang, dan KEK Tanjung Lesung.

Kebutuhan air tertinggi pada DAS Ciliman digunakan untuk mengairi irigasi ciliman sebesar yaitu $136.529 .448 \mathrm{~m}^{3}$. Kebutuhan air pada masingmasing sektor tidak secara keseluruhan dapat dipenuhi. Pada bulan Juli, Agustus, September dan
November beberapa kebutuhan tidak dapat terpenuhi oleh ketersediaan air. Untuk kebutuhan Air Baku pada DAS Ciliman mengalami ketercukupan sebesar $100 \%$ kecuali di Bulan Agustus untuk air baku cirinten hanya tercukupi sebesar 0,04\%, air baku sukaresmi tercukupi sebesar $11,69 \%$, air baku gunung kencana tercukupi sebesar 99,93\%, sedangkan air baku panimbang tercukupi sebesar $84,36 \%$. Demikian pula dengan kebutuhan air bandara dan KEK Tanjung Lesung mengalami ketercukupan sebesar $100 \%$ kecuali di bulan Agustus dan September hanya terpenuhi sebesar 5\% dan 30,27\% (KEK Tanjung Lesung) serta 0,01\% dan 30,60\% (Bandara).

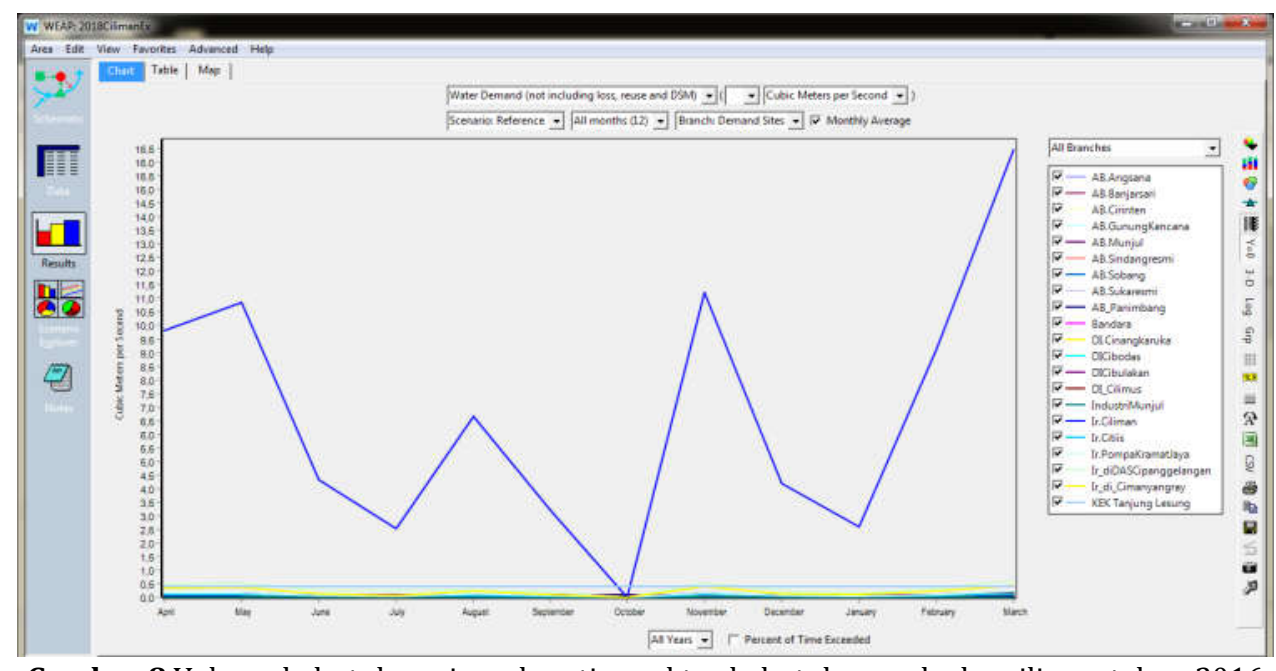

Gambar 8 Volume kebutuhan air pada setiap sektor kebutuhan pada das ciliman tahun 2016

Kegagalan pasokan air DAS Ciliman terjadi di bulan Mei (0,01 $\mathrm{m}^{3} /$ detik), Juli $\left(1,97 \mathrm{~m}^{3} /\right.$ detik), Agustus (7,72 $\mathrm{m}^{3} /$ detik), September $(2,69$ $\mathrm{m}^{3} /$ detik), dan November $\left(1,12 \mathrm{~m}^{3} /\right.$ detik). Pada 5 bulan tersebut, beberapa kebutuhan tidak dapat terpenuhi oleh ketersediaan air karena data debit andalan pada tiap Sub DAS Ciliman cenderung berkurang mendekati kebutuhan. Pada Bulan Mei dan November kegagalan pasokan air relatif kecil karena berada pada musim penghujan. Kondisi yang perlu mendapatkan perhatian yaitu pada Bulan Juli September, perlu diatur prioritas pemenuhan kebutuhan airnya karena ketersediaan airnya pada 3 bulan tersebut relatif kurang mendekati jumlah kebutuhan air. Pada Bulan Mei yaitu irigasi cipanggelangan sebesar 0,01 $\mathrm{m}^{3} /$ detik, kemudian pada Bulan Juli kegagalan pasokan air bertambah menjadi $1,97 \mathrm{~m}^{3} /$ detik, yaitu terjadi di irigasi cinangkaruka $\left(0,03 \mathrm{~m}^{3} /\right.$ detik), irigasi ciliman $(1,62$ $\mathrm{m}^{3} /$ detik), irigasi citiis $\left(0,05 \mathrm{~m}^{3} /\right.$ detik), irigasi cipanggelangan $\left(0,25 \quad \mathrm{~m}^{3} /\right.$ detik), irigasi cimanyangray $\left(0,01 \mathrm{~m}^{3} /\right.$ detik), dan irigasi pompa kramatjaya $\left(0,02 \mathrm{~m}^{3} /\right.$ detik). Sedangkan pada Bulan Agustus, kegagalan pasokan air semakin bertambah menjadi $7,72 \mathrm{~m}^{3} /$ detik, yaitu terjadi irigasi ciliman $\left(6,44 \mathrm{~m}^{3} /\right.$ detik $)$, irigasi citiis $\left(0,06 \mathrm{~m}^{3} /\right.$ detik $)$, irigasi pompa kramat jaya $\left(0,12 \mathrm{~m}^{3} /\right.$ detik), irigasi cibodas $\left(0,06 \mathrm{~m}^{3} /\right.$ detik $)$, irigasi cipanggelangan $(0,26$ $\mathrm{m}^{3} /$ detik), irigasi cimanyangray $\left(0,2 \mathrm{~m}^{3} /\right.$ detik), irigasi cinangkaruka $\left(0,05 \mathrm{~m}^{3} /\right.$ detik $)$, irigasi cibulakan $\left(0,03 \mathrm{~m}^{3} /\right.$ detik $)$, irigasi cilimus $(0,02$ $\mathrm{m}^{3} /$ detik), air baku panimbang $\left(0,01 \mathrm{~m}^{3} /\right.$ detik), air baku sukaresmi $\left(0,05 \mathrm{~m}^{3} /\right.$ detik $)$, air baku cirinten $\left(0,04 \mathrm{~m}^{3} /\right.$ detik), bandara $\left(0,01 \mathrm{~m}^{3} /\right.$ detik $)$, dan KEK Tanjung Lesung $\left(0,38 \mathrm{~m}^{3} /\right.$ detik $)$. Pada Bulan September, kegagalan pasokan air berkurang menjadi 2,69 $\mathrm{m}^{3} /$ detik dan gagal memenuhi kebutuhan untuk 7 permintaan yaitu irigasi ciliman $\left(2,14 \mathrm{~m}^{3} /\right.$ detik $)$, irigasi cipanggelangan $(0,16$ $\mathrm{m}^{3} /$ detik), irigasi cimanyangray $\left(0,04 \mathrm{~m}^{3} /\right.$ detik), irigasi citiis $\left(0,02 \mathrm{~m}^{3} /\right.$ detik), irigasi pompa kramatjaya $\left(0,04 \mathrm{~m}^{3} /\right.$ detik $)$, bandara $(0,01$ $\mathrm{m}^{3} /$ detik), dan KEK Tanjung Lesung $\left(0,28 \mathrm{~m}^{3} /\right.$ detik). Kemudian pada Bulan November hanya gagal memasok kebutuhan air untuk irigasi ciliman sebesar $0,88 \mathrm{~m}^{3} /$ detik, irigasi cipanggelangan sebesar $0,23 \mathrm{~m}^{3} /$ detik dan irigasi pompa kramatjaya sebesar 0,01 $\mathrm{m}^{3} /$ detik.Secara umum, besarnya kekurangan pasokan air yang terjadi pada DAS Ciliman tersaji dalam Gambar 9. 


\subsection{Analisis Pengembangan Prasarana}

Berdasarkan hasil perhitungan neraca air dan alokasi air menggunakan aplikasi WEAP pada DAS Ciliman dengan kondisi eksisting pada tahun 2016 hingga tahun proyeksi 2036, ternyata DAS Ciliman tidak mampu memasok kebutuhan air terutama pada musim kemarau di Bulan Juli, Agustus dan September, sehingga diperlukan skenario pengembangan prasarana sumber daya air untuk menampung kelebihan air di musim penghujan untuk dimanfaatkan pada waktu yang diperlukan. Berdasarkan Hasil Pra Feasilibility Studi Pembangunan Multipurpose DAM pada DAS Ciliman yang telah dilakukan sebelumnya untuk mendapatkan rekomendasi alternatif-alternatif, dan perencanaan desain bangunan bendungan utama dan bangunan pelengkap, diperoleh 3 (tiga) alternatif pengembangan bendungan pada DAS Ciliman seperti terlihat pada Gambar 10.

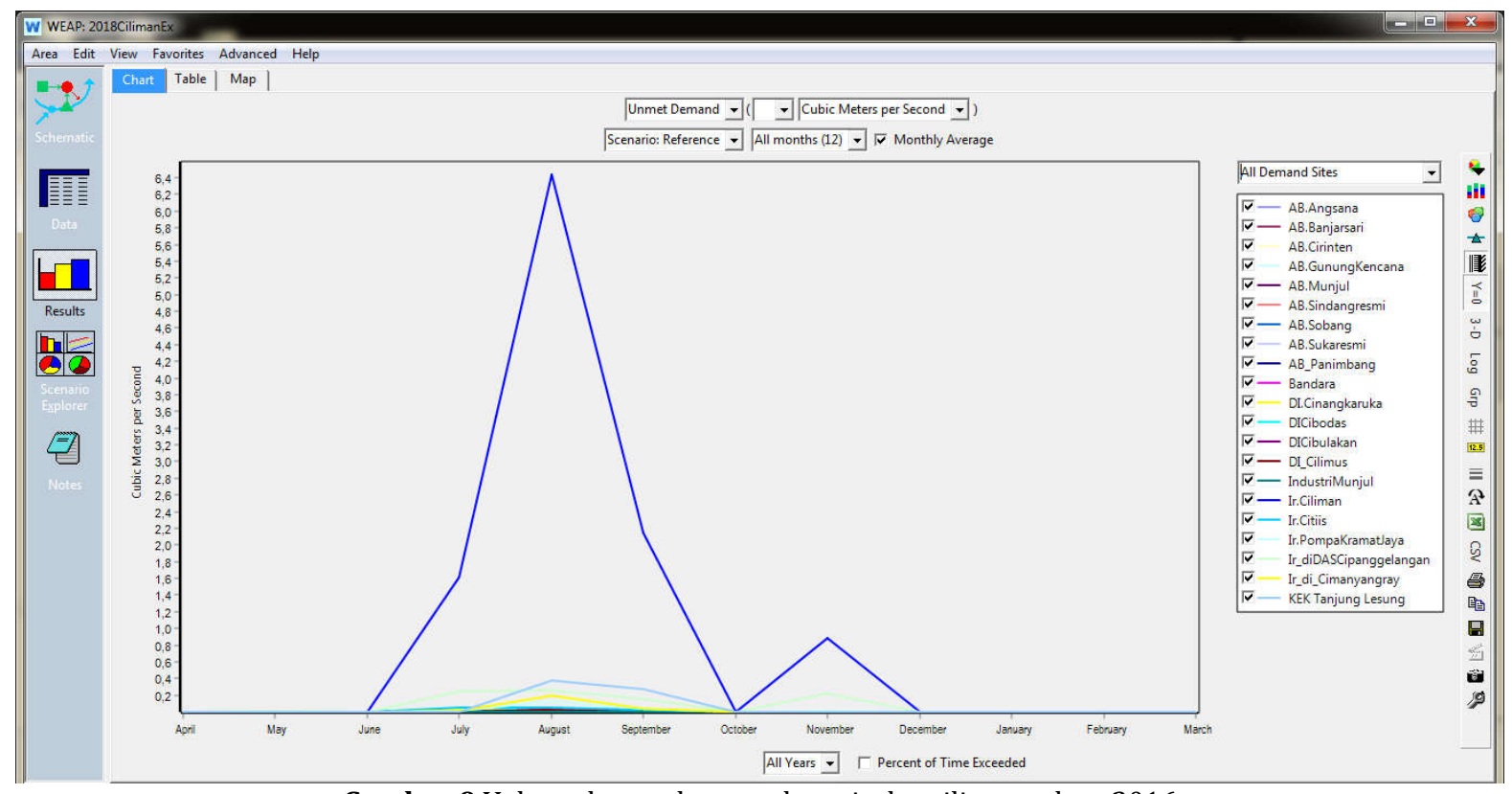

Gambar 9 Volume kegagalan pasokan air das ciliman tahun 2016

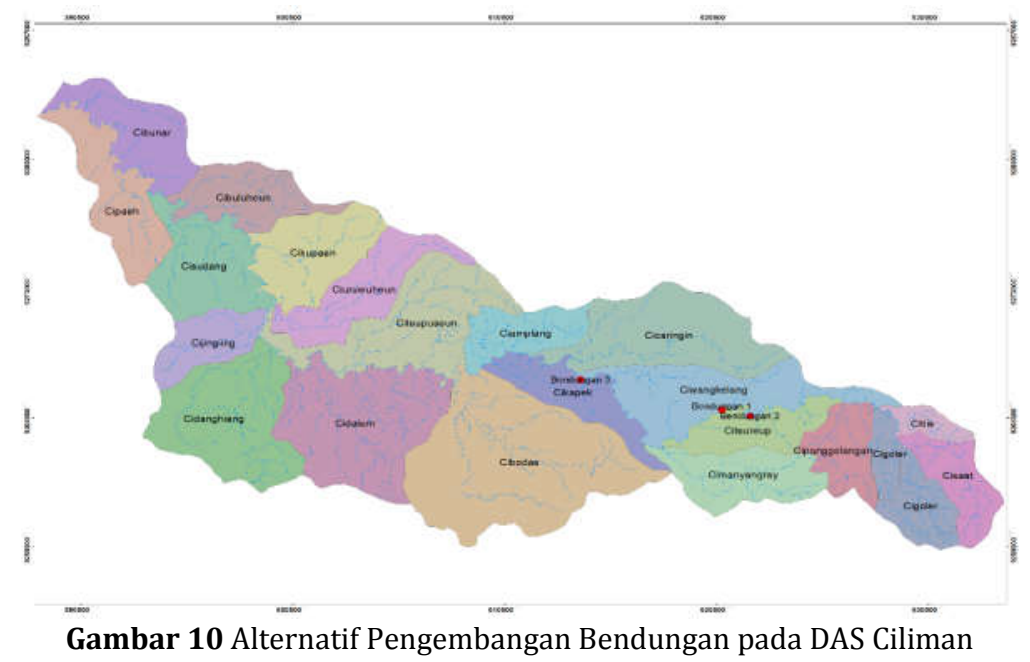

\section{A. Operasi Alternatif Bendungan Pada Daerah} Studi

Operasi 3 (tiga) buah alternatif bendungan yang diperhitungkan dalam penelitian ini mengacu pada hasil perhitungan Pra Feasilibility Studi Pembangunan Multipurpose DAM pada DAS Ciliman, dengan kapasitas tampung bendungan alternatif 1 , alternatif 2 dan alternatif 3 masing-masing sebesar
15,08 juta meter ${ }^{3}, 16,32$ juta meter ${ }^{3}$ dan 44,67 juta meter $^{3}$ serta kapasitas tampungan awal sebesar 8,13 juta meter ${ }^{3}, 11,57$ juta meter ${ }^{3}$ dan 31,38 juta meter ${ }^{3}$. Data masukkan untuk reservoir atau bendungan Ciliman adalah berupa data fisik dan operasional bendungan. Dari ketiga alternatif bendungan diatas, data fisik bendungan yang diperlukan sebagai input dalam WEAP dapat dilihat pada Tabel 1. 
Tabel 1. Parameter fisik dan operasi 4 alternatif bendungan di ciliman

\begin{tabular}{lccccc}
\hline & & \multicolumn{3}{c}{ Dalam Juta Meter ${ }^{3}$} \\
\hline \multicolumn{1}{c}{ Parameter Fisik } & Bendungan 1 & Bendungan 2 & Bendungan 3 & \multicolumn{2}{c}{ Bendungan 2+3 $^{2}$} \\
\hline Storage capacity & 15.08 & 16.32 & 44.67 & 16.32 & 44.67 \\
Initial Storage & 8.13 & 11,57 & 31.38 & 11,57 & 31.38 \\
Volume Elevation Curve & lihat gambar & lihat gambar & lihat gambar & lihat gambar & lihat gambar \\
\hline \multicolumn{1}{c}{ Parameter Operasi } & Bendungan 1 & Bendungan 2 & Bendungan 3 & Bendungan 2 & Bendungan 3 \\
\hline Top conservation & 8.13 & 11.57 & 31.38 & 11.57 & 31.38 \\
Top Bufer & 1 & 1 & 3,5 & 1 & 3,5 \\
Top Inactive & 0.82 & 0.72 & 0.92 & 0.72 & 0.92 \\
\hline
\end{tabular}

Sumber : Hasil Analisis, 2018

Tabel 2. Inflow Outflow Bendung Ciliman

\begin{tabular}{|c|c|c|c|c|c|c|c|c|c|c|c|c|c|}
\hline Bendungan $2+3$ & Apr & Mei & Jun & Jul & Aug & Sep & Okt & Nov & Des & Jan & Feb & Mar & Sum \\
\hline $\begin{array}{l}\text { Decrease in Storage for } \\
\text { Bendungan2 }\end{array}$ & & & & & 0,5 & 5,2 & 5,2 & & & & & & 10,8 \\
\hline $\begin{array}{l}\text { Decrease in Storage for } \\
\text { Bendungan3 }\end{array}$ & & & & 4,4 & 18,1 & & & 19,9 & & & & & 42,4 \\
\hline $\begin{array}{l}\text { Increase in Storage for } \\
\text { Bendungan2 }\end{array}$ & - & - & - & - & & & & $-1,6$ & $-5,9$ & $-3,3$ & - & - & $-10,8$ \\
\hline $\begin{array}{l}\text { Increase in Storage for } \\
\text { Bendungan3 }\end{array}$ & - & - & - & & & $-6,5$ & -10 & & -17 & $-9,2$ & - & - & $-42,4$ \\
\hline $\begin{array}{l}\text { Inflow from Upstream } \\
\text { Net Evaporation }\end{array}$ & 57,3 & 37,5 & 18,5 & 1,3 & 0,3 & 7,3 & 13,1 & 14,7 & 29,2 & 41 & 46,5 & 58,2 & $\begin{array}{c}324,9 \\
0,0\end{array}$ \\
\hline Outflow to Downstream & -57 & -38 & -19 & $-5,7$ & -19 & -6 & $-8,2$ & -33 & $-6,7$ & -29 & -47 & -58 & $-324,9$ \\
\hline Sum & 0 & 0 & 0 & - & 0 & 0 & 0 & 0 & 0 & 0 & 0 & - & 0,0 \\
\hline Bendungan 3 & Apr & Mei & Jun & Jul & Aug & Sep & Okt & Nov & Des & Jan & Feb & Mar & Sum \\
\hline $\begin{array}{l}\text { Decrease in Storage for } \\
\text { Bendungan3 }\end{array}$ & & & & 4,4 & 18,1 & & & 13,2 & & & & & 35,8 \\
\hline $\begin{array}{l}\text { Increase in Storage for } \\
\text { Bendungan3 }\end{array}$ & 0 & 0 & 0 & & & $-1,3$ & $-4,3$ & & -21 & $-9,4$ & 0 & 0 & $-35,8$ \\
\hline Inflow from Upstream & 34,2 & 22,9 & 11,1 & 0,8 & 0,2 & 1,3 & 4,3 & 9,7 & 20,8 & 25,4 & 26,9 & 34,9 & 192,5 \\
\hline Net Evaporation & 0 & 0 & 0 & 0 & 0 & 0 & 0 & 0 & 0 & 0 & 0 & 0 & 0 \\
\hline Outflow to Downstream & $-34,2$ & $-22,9$ & $-11,1$ & $-5,3$ & $-18,3$ & 0,0 & 0,0 & $-22,9$ & 0,0 & $-16,0$ & $-26,9$ & $-34,9$ & $-192,5$ \\
\hline Sum & 0 & 0 & 0 & 0 & 0 & 0 & 0 & 0 & 0 & 0 & 0 & 0 & 0 \\
\hline Bendungan 2 & Apr & Mei & Jun & Jul & Aug & Sep & Okt & Nov & Des & Jan & Feb & Mar & Sum \\
\hline $\begin{array}{l}\text { Decrease in Storage for } \\
\text { Bendungan2 }\end{array}$ & & & & 4,7 & 6,2 & 0 & & 2,1 & & & & & 13,0 \\
\hline $\begin{array}{l}\text { Increase in Storage for } \\
\text { Bendungan2 }\end{array}$ & 0 & 0 & 0 & & & 0 & $-3,0$ & & $-10,0$ & 0 & 0 & 0 & $-13,0$ \\
\hline Inflow from Upstream & 20,2 & 12,9 & 6,5 & 0,5 & 0 & 0,8 & 3 & 6,3 & 12,6 & 16,8 & 17,2 & 20,6 & 117,4 \\
\hline Net Evaporation & 0 & 0 & 0 & 0 & 0 & 0 & 0 & 0 & 0 & 0 & 0 & 0 & 0 \\
\hline Outflow to Downstream & $-20,2$ & $-12,9$ & $-6,5$ & $-5,1$ & $-6,2$ & $-0,8$ & 0,0 & $-8,4$ & $-2,6$ & $-16,8$ & $-17,2$ & $-20,6$ & $-117,4$ \\
\hline Sum & 0 & 0 & 0 & 0 & 0 & 0 & 0 & 0 & 0 & 0 & 0 & 0 & 0 \\
\hline Bendungan 1 & Apr & Mei & Jun & Jul & Aug & Sep & Okt & Nov & Des & Jan & Feb & Mar & Sum \\
\hline $\begin{array}{l}\text { Decrease in Storage for } \\
\text { Bendungan1 }\end{array}$ & & & & 4,6 & 2,7 & 0 & & 1,0 & & & & & 8,3 \\
\hline $\begin{array}{l}\text { Increase in Storage for } \\
\text { Bendungan1 }\end{array}$ & 0 & 0 & 0 & & & 0 & $-3,0$ & & $-5,3$ & 0 & 0 & 0 & $-8,3$ \\
\hline Inflow from Upstream & 22,8 & 14,9 & 7,4 & 0,6 & 0,1 & 1 & 3,2 & 7,1 & 14,1 & 18,5 & 18,9 & 23,5 & 132,1 \\
\hline Net Evaporation & 0 & 0 & 0 & 0 & 0 & 0 & 0 & 0 & 0 & 0 & 0 & 0 & 0 \\
\hline Outflow to Downstream & $-22,8$ & $-14,9$ & $-7,4$ & $-5,2$ & $-2,8$ & $-1,0$ & $-0,3$ & $-8,1$ & $-8,8$ & $-18,5$ & $-18,9$ & $-23,5$ & $-132,1$ \\
\hline Sum & 0 & 0 & 0 & 0 & 0 & 0 & 0 & 0 & 0 & 0 & 0 & 0 & 0 \\
\hline
\end{tabular}

Sumber : Hasil analisis, 2018

\section{B. Skenario simulasi}

Simulasi dilakukan dengan periode simulasi 20 tahun. Sebagai tahun awal simulasi, sesuai dengan ketersediaan data, adalah tahun 2016. Berikut ini skenario dari simulasi neraca air dengan WEAP di DAS Ciliman :

a) Kondisi Eksisting

Simulasi dengan WEAP ini merupakan simulasi terhadap kondisi yang ada sekarang. Tujuan simulasi ini untuk mengetahui apakah masih tersedia air dari Sungai Ciliman untuk pemenuhan kebutuhan air baku di semua Kecamatan di DAS Ciliman dan irigasi serta mengkaji potensi untuk pemenuhan KEK Tanjung Lesung dan Bandara Panimbang dari Sungai Ciliman. Urutan prioritas pemenuhan irigasi di sub DAS, kebutuhan air domestik, DI Ciliman, bandara, dan KEK Tanjung Lesung. Irigasi yang mengambil air dari anak sungai Ciliman dianggap prioritas pertama karena mengambil air untuk kebutuhannya lebih dulu sebelum air mengalir ke Sungai Ciliman (irigasi citiis, irigasi cipanggelangan, irigasi cibodas, irigasi cimanyangray, irigasi cinangkaruka, irigasi cibulakan, dan irigasi cilimus), kemudian prioritas kedua adalah air baku. Prioritas ketiga adalah irigasi ciliman dan irigasi pompa kramatjaya. Prioritas keempat adalah air baku sukaresmi, air baku panimbang, dan industri munjul serta prioritas kelima adalah bandara dan KEK tanjung lesung. 
b) Kondisi dengan adanya Bendungan 1 di Sungai Ciliman

Simulasi dengan WEAP ini merupakan simulasi terhadap kondisi dengan adanya bendungan 1 di Sungai Ciliman. Tujuan simulasi ini untuk mengetahui pengaruh adanya bendungan 1 terhadap pemenuhan kebutuhan air baku di semua Kecamatan di DAS Ciliman dan irigasi serta mengkaji potensi untuk pemenuhan KEK Tanjung Lesung dan Bandara Panimbang dari Sungai Ciliman. Urutan prioritas pemenuhan irigasi di sub DAS, kebutuhan air domestik, bandara, dan KEK Tanjung Lesung, dan
DI Ciliman. Irigasi yang mengambil air dari anak sungai Ciliman dianggap prioritas pertama karena mengambil air untuk kebutuhannya lebih dulu sebelum air mengalir ke Sungai Ciliman (irigasi citiis, irigasi cipanggelangan, irigasi cibodas, irigasi cimanyangray dan irigasi cinangkaruka), kemudian prioritas kedua adalah air baku, prioritas ketiga adalah air baku sukaresmi, air baku panimbang, irigasi cilimus, irigasi cibulakan, irigasi pompa kramatjaya, bandara dan KEK tanjung lesung. Prioritas keempat adalah industri munjul dan prioritas kelima irigasi ciliman.

Tabel 3. Persentase rata-rata pemenuhan kebutuhan air DAS Ciliman tahun 2016- 2036 Skenario Eksisting

\begin{tabular}{|c|c|c|c|c|c|c|c|c|c|c|c|c|}
\hline \multicolumn{13}{|c|}{ (\% of requirement met) (Percent) } \\
\hline & Apr & Mei & Jun & Jul & Ags & Sep & Okt & Nov & Des & Jan & Feb & Mar \\
\hline ABAngsana & 100.00 & 100.00 & 100.00 & 100.00 & 100.00 & 100.00 & 100.00 & 100.00 & 100.00 & 100.00 & 100.00 & 100.00 \\
\hline ABBanjarsari & 100.00 & 100.00 & 100.00 & 100.00 & 100.00 & 100.00 & 100.00 & 100.00 & 100.00 & 100.00 & 100.00 & 100.00 \\
\hline ABCirinten & 100.00 & 100.00 & 100.00 & 100.00 & 0.04 & 100.00 & 100.00 & 100.00 & 100.00 & 100.00 & 100.00 & 100.00 \\
\hline ABGunungKencana & 100.00 & 100.00 & 100.00 & 100.00 & 99.93 & 100.00 & 100.00 & 100.00 & 100.00 & 100.00 & 100.00 & 100.00 \\
\hline ABMunjul & 100.00 & 100.00 & 100.00 & 100.00 & 100.00 & 100.00 & 100.00 & 100.00 & 100.00 & 100.00 & 100.00 & 100.00 \\
\hline ABSindangresmi & 100.00 & 100.00 & 100.00 & 100.00 & 100.00 & 100.00 & 100.00 & 100.00 & 100.00 & 100.00 & 100.00 & 100.00 \\
\hline ABSobang & 100.00 & 100.00 & 100.00 & 100.00 & 100.00 & 100.00 & 100.00 & 100.00 & 100.00 & 100.00 & 100.00 & 100.00 \\
\hline ABSukaresmi & 100.00 & 100.00 & 100.00 & 100.00 & 11.69 & 100.00 & 100.00 & 100.00 & 100.00 & 100.00 & 100.00 & 100.00 \\
\hline AB_Panimbang & 100.00 & 100.00 & 100.00 & 100.00 & 84.36 & 100.00 & 100.00 & 100.00 & 100.00 & 100.00 & 100.00 & 100.00 \\
\hline Bandara & 100.00 & 100.00 & 100.00 & 100.00 & 0.01 & 30.60 & 100.00 & 100.00 & 100.00 & 100.00 & 100.00 & 100.00 \\
\hline DICinangkaruka & 100.00 & 100.00 & 100.00 & 55.97 & 19.41 & 100.00 & 100.00 & 100.00 & 100.00 & 100.00 & 100.00 & 100.00 \\
\hline DICibodas & 100.00 & 100.00 & 100.00 & 100.00 & 46.11 & 100.00 & 100.00 & 100.00 & 100.00 & 100.00 & 100.00 & 100.00 \\
\hline DICibulakan & 100.00 & 100.00 & 100.00 & 100.00 & 72.49 & 100.00 & 100.00 & 100.00 & 100.00 & 100.00 & 100.00 & 100.00 \\
\hline DI_Cilimus & 100.00 & 100.00 & 100.00 & 100.00 & 72.49 & 100.00 & 100.00 & 100.00 & 100.00 & 100.00 & 100.00 & 100.00 \\
\hline IndustriMunjul & 100.00 & 100.00 & 100.00 & 100.00 & 40.55 & 100.00 & 100.00 & 100.00 & 100.00 & 100.00 & 100.00 & 100.00 \\
\hline IrCiliman & 100.00 & 100.00 & 100.00 & 36.16 & 3.18 & 32.85 & 100.00 & 92.10 & 100.00 & 100.00 & 100.00 & 100.00 \\
\hline IrCitiis & 100.00 & 100.00 & 100.00 & 17.11 & - & 45.55 & 100.00 & 100.00 & 100.00 & 100.00 & 100.00 & 100.00 \\
\hline IrPompaKramatJaya & 100.00 & 100.00 & 100.00 & 37.30 & - & 33.69 & 100.00 & 93.56 & 100.00 & 100.00 & 100.00 & 100.00 \\
\hline Ir_diDASCipanggelangan & 100.00 & 98.29 & 100.00 & 10.74 & 3.67 & 23.57 & 100.00 & 57.80 & 100.00 & 100.00 & 100.00 & 100.00 \\
\hline Ir_di_Cimanyangray & 100.00 & 100.00 & 100.00 & 83.96 & 9.21 & 61.99 & 100.00 & 100.00 & 100.00 & 100.00 & 100.00 & 100.00 \\
\hline KEK Tanjung Lesung & 100.00 & 100.00 & 100.00 & 100.00 & 5.00 & 30.27 & 100.00 & 100.00 & 100.00 & 100.00 & 100.00 & 100.00 \\
\hline
\end{tabular}

Tabel 4. Persentase rata-rata pemenuhan kebutuhan air DAS Ciliman tahun 2016- 2036 Skenario Bendungan Ciliman (Alt 1)

\begin{tabular}{|c|c|c|c|c|c|c|c|c|c|c|c|c|}
\hline & Apr & Mei & Jun & Jul & Ags & Sep & Okt & Nov & Des & Jan & Feb & Mar \\
\hline ABAngsana & 100.00 & 100.00 & 100.00 & 100.00 & 100.00 & 100.00 & 100.00 & 100.00 & 100.00 & 100.00 & 100.00 & 100.00 \\
\hline ABBanjarsari & 100.00 & 100.00 & 100.00 & 100.00 & 100.00 & 100.00 & 100.00 & 100.00 & 100.00 & 100.00 & 100.00 & 100.00 \\
\hline ABCirinten & 00.00 & 100.00 & 00.00 & 100.00 & 100.00 & 100.00 & 100.00 & 100.00 & 100.00 & 100.00 & 100.00 & 100.00 \\
\hline ABMunjul & 00.00 & 100.00 & 100.00 & 100.00 & 100.00 & 100.00 & 100.00 & 100.00 & 100.00 & 100.00 & 100.00 & 100.00 \\
\hline ABSindangr & 100.00 & 100.00 & 100.00 & 100.00 & 100.00 & 100.00 & 100.00 & 100.00 & 100.00 & 100.00 & 100.00 & 100.00 \\
\hline ABSobang & 100.00 & 100.00 & 100.00 & 100.00 & 100.00 & 100.00 & 100.00 & 100.00 & & 100 & 100.00 & 100.00 \\
\hline ABSukar & 00.00 & 100.00 & 100.00 & 100 & 100 & 100 & 100.00 & 100.00 & & 10 & 10 & 10 \\
\hline AB_Panimbang & 100.00 & 100.00 & 100.00 & 100.00 & 100.00 & 100.00 & 100.00 & 100.00 & 100.00 & 100.00 & 100.00 & 100.00 \\
\hline Bañdara & 100.00 & 100.00 & 100.00 & 100.00 & 100.00 & 100 & 100.00 & 100 & & 10 & 00 & .00 \\
\hline DICin & 00.00 & 100.00 & 100.00 & 100.00 & 37.15 & 100.00 & 100.00 & 100.00 & 10 & 100.00 & 100.00 & 100.00 \\
\hline DICibo & 100.00 & 100.00 & 100.00 & 10 & & 10 & 100 & 100 & & 10 & 10 & 00 \\
\hline DICil & 0 & 100.00 & 100 & 10 & 60 & 10 & 100 & 100 & & 10 & & .00 \\
\hline DI_Cilimus & & 100.00 & 100.00 & 100.00 & 100.00 & 100.00 & 100.00 & 100.00 & & 100 & 100 & 100.00 \\
\hline Indus & 100.00 & 100.00 & 100.00 & 100.00 & 100.00 & 100.00 & 100.00 & 100.00 & & 10 & & 100.00 \\
\hline IrCiliman & 100.00 & 100.00 & 100.00 & 100.00 & 9.86 & & 100.00 & 99.00 & & 100.00 & 10 & 100.00 \\
\hline IrCitiis & 100.00 & 100.00 & 100.00 & 17.12 & - & 45.56 & 100.00 & 100.00 & 10 & 100.00 & 100.00 & 100.00 \\
\hline Ir_diDASCipanggelangan & & & & & & & & & & & & 100.00 \\
\hline Ir_di_Cimanyangray & 100.00 & 100.00 & 100.00 & & 9.23 & 62.01 & 100.00 & 100.00 & & 100.00 & 100.00 & 100.00 \\
\hline KEK Tanjung Lesung & 100.00 & 100.00 & 100.00 & 100.00 & 100.00 & 100.00 & 100.00 & 100.00 & 100.00 & 100.00 & 100.00 & 100.00 \\
\hline
\end{tabular}
Sumber : Hasil analisis, 2018

c) Kondisi dengan adanya Bendungan 2 di Sungai Ciliman

Simulasi dengan WEAP ini merupakan simulasi terhadap kondisi dengan adanya bendungan 2 di Sungai Ciliman. Tujuan simulasi ini untuk mengetahui pengaruh adanya bendungan 2 183 terhadap pemenuhan kebutuhan air baku di semua Kecamatan di DAS Ciliman dan irigasi serta mengkaji potensi untuk pemenuhan KEK Tanjung Lesung dan Bandara Panimbang dari Sungai Ciliman. Urutan prioritas yaitu untuk prioritas 1 adalah irigasi citiis, irigasi cipanggelangan, irigasi cibodas, irigasi 
cimanyangray, irigasi cinangkaruka, irigasi cilimus, dan irigasi cibulakan. Prioritas kedua adalah air baku. Prioritas ketiga adalah air baku sukaresmi, air baku panimbang, irigasi pompa kramatjaya, bandara dan KEK tanjung lesung. Prioritas keempat adalah industri munjul dan prioritas kelima adalah pengembangan irigasi ciliman seluas 200 hektar. Prioritas keenam adalah irigasi ciliman.

Tabel 5. Persentase rata-rata pemenuhan kebutuhan air DAS Ciliman

(tahun 2016- 2036) Skenario Bendungan Ciliman (Alt 2)

\begin{tabular}{|c|c|c|c|c|c|c|c|c|c|c|c|c|}
\hline & Apr & Mei & Jun & Jul & Ags & Sep & Okt & Nov & Des & Jan & Feb & Mar \\
\hline ABAngsana & 100.00 & 100.00 & 100.00 & 100.00 & 100.00 & 100.00 & 100.00 & 100.00 & 100.00 & 100.00 & 100.00 & 100.00 \\
\hline ABBanjarsari & 100.00 & 100.00 & 100.00 & 100.00 & 100.00 & 100.00 & 100.00 & 100.00 & 100.00 & 100.00 & 100.00 & 100.00 \\
\hline ABCirinten & 100.00 & 100.00 & 100.00 & 100.00 & 8.73 & 100.00 & 100.00 & 100.00 & 100.00 & 100.00 & 100.00 & 100.00 \\
\hline ABGunungKencana & 100.00 & 100.00 & 100.00 & 100.00 & 100.00 & 100.00 & 100.00 & 100.00 & 100.00 & 100.00 & 100.00 & 100.00 \\
\hline ABMunjul & 100.00 & 100.00 & 100.00 & 100.00 & 100.00 & 100.00 & 100.00 & 100.00 & 100.00 & 100.00 & 100.00 & 100.00 \\
\hline ABSindangresmi & 100.00 & 100.00 & 100.00 & 100.00 & 100.00 & 100.00 & 100.00 & 100.00 & 100.00 & 100.00 & 100.00 & 100.00 \\
\hline ABSobang & 100.00 & 100.00 & 100.00 & 100.00 & 100.00 & 100.00 & 100.00 & 100.00 & 100.00 & 100.00 & 100.00 & 100.00 \\
\hline ABSukaresmi & 100.00 & 100.00 & 100.00 & 100.00 & 100.00 & 100.00 & 100.00 & 100.00 & 100.00 & 100.00 & 100.00 & 100.00 \\
\hline AB_Panimbang & 100.00 & 100.00 & 100.00 & 100.00 & 100.00 & 100.00 & 100.00 & 100.00 & 100.00 & 100.00 & 100.00 & 100.00 \\
\hline Bañdara & 100.00 & 100.00 & 100.00 & 100.00 & 100.00 & 100.00 & 100.00 & 100.00 & 100.00 & 100.00 & 100.00 & 100.00 \\
\hline DICinangkaruka & 100.00 & 100.00 & 100.00 & 100.00 & 37.15 & 100.00 & 100.00 & 100.00 & 100.00 & 100.00 & 100.00 & 100.00 \\
\hline DICibodas & 100.00 & 100.00 & 100.00 & 100.00 & 46.11 & 100.00 & 100.00 & 100.00 & 100.00 & 100.00 & 100.00 & 100.00 \\
\hline DICibulakan & 100.00 & 100.00 & 100.00 & 100.00 & 100.00 & 100.00 & 100.00 & 100.00 & 100.00 & 100.00 & 100.00 & 100.00 \\
\hline DI_Cilimus & 100.00 & 100.00 & 100.00 & 100.00 & 100.00 & 100.00 & 100.00 & 100.00 & 100.00 & 100.00 & 100.00 & 100.00 \\
\hline IndustriMunjul & 100.00 & 100.00 & 100.00 & 100.00 & 100.00 & 100.00 & 100.00 & 100.00 & 100.00 & 100.00 & 100.00 & 100.00 \\
\hline IrCiliman & 100.00 & 100.00 & 100.00 & 100.00 & 29.15 & 23.11 & 100.00 & 99.00 & 100.00 & 100.00 & 100.00 & 100.00 \\
\hline IrCitiis & 100.00 & 100.00 & 100.00 & 17.12 & - & 45.55 & 100.00 & 100.00 & 100.00 & 100.00 & 100.00 & 100.00 \\
\hline IrPompaKramatJaya & 100.00 & 100.00 & 100.00 & 100.00 & 100.00 & 100.00 & 100.00 & 100.00 & 100.00 & 100.00 & 100.00 & 100.00 \\
\hline Ir_diDASCipanggelangan & 100.00 & 98.29 & 100.00 & 10.76 & 3.67 & 23.57 & 100.00 & 57.81 & 100.00 & 100.00 & 100.00 & 100.00 \\
\hline Ir_di_Cimanyangray & 100.00 & 100.00 & 100.00 & 83.96 & 9.21 & 62.00 & 100.00 & 100.00 & 100.00 & 100.00 & 100.00 & 100.00 \\
\hline KEK Tanjung Lesung & 100.00 & 100.00 & 100.00 & 100.00 & 100.00 & 100.00 & 100.00 & 100.00 & 100.00 & 100.00 & 100.00 & 100.00 \\
\hline ZZ_DICilimanExp & 100.00 & 100.00 & 100.00 & 95.27 & 0.31 & 0.27 & 100.00 & 95.24 & 100.00 & 100.00 & 100.00 & 100.00 \\
\hline
\end{tabular}

Tabel 6. Persentase rata-rata pemenuhan kebutuhan air DAS Ciliman tahun 2016- 2036 Skenario Bendungan Ciliman (Alt 3)

\begin{tabular}{|c|c|c|c|c|c|c|c|c|c|c|c|c|}
\hline & Apr & Mei & Jun & Jul & Ags & Sep & Okt & Nov & Des & Jan & Feb & Mar \\
\hline ABAngsana & 100.00 & 100.00 & 100.00 & 100.00 & 100.00 & 100.00 & 100.00 & 100.00 & 100.00 & 100.00 & 100.00 & 100.00 \\
\hline ABBanjarsari & 100.00 & 100.00 & 100.00 & 100.00 & 100.00 & 100.00 & 100.00 & 100.00 & 100.00 & 100.00 & 100.00 & 100.00 \\
\hline ABCirinten & 100.00 & 100.00 & 100.00 & 100.00 & 0.05 & 100.00 & 100.00 & 100.00 & 100.00 & 100.00 & 100.00 & 100.00 \\
\hline ABMunjul & 100.00 & 100.00 & 100.00 & 100.00 & 100.00 & 100.00 & 100.00 & 100.00 & 100.00 & 100.00 & 100.00 & 100.00 \\
\hline ABSindangresmi & 100.00 & 100.00 & 100.00 & 100.00 & 100.00 & 100.00 & 100.00 & 100.00 & 100.00 & 100.00 & 100.00 & 100.00 \\
\hline ABSobang & 100.00 & 100.00 & 100.00 & 100.00 & 100.00 & 100.00 & 100.00 & 100.00 & 100.00 & 100.00 & 100.00 & 100.00 \\
\hline ABSukaresmi & 100.00 & 100.00 & 100.00 & 100.00 & 100.00 & 100.00 & 100.00 & 100.00 & 100.00 & 100.00 & 100.00 & 100.00 \\
\hline AB_Panimbang & 100.00 & 100.00 & 100.00 & 100.00 & 100.00 & 100.00 & 100.00 & 100.00 & 100.00 & 100.00 & 100.00 & 100.00 \\
\hline Bandara & 100.00 & 100.00 & 100.00 & 100.00 & 100.00 & 100.00 & 100.00 & 100.00 & 100.00 & 100.00 & 100.00 & 100.00 \\
\hline DICinangkaruka & 100.00 & 100.00 & 100.00 & 100.00 & 37.15 & 100.00 & 100.00 & 100.00 & 100.00 & 100.00 & 100.00 & 100.00 \\
\hline DICibodas & & 100.00 & & & & & & & & 100.00 & & 100.00 \\
\hline DICibulakan & 100.00 & 100.00 & 100.00 & 100.00 & 73.76 & 100.00 & 100.00 & 100.00 & 100.00 & 100.00 & 100.00 & 100.00 \\
\hline DI_Cilimus & 100.00 & 100.00 & 100.00 & 100.00 & 73.76 & 100.00 & 100.00 & 100.00 & 100.00 & 100.00 & 100.00 & 100.00 \\
\hline IndustriMunjul & 100.00 & 100.00 & 100.00 & 100.00 & 100.00 & 100.00 & 100.00 & 100.00 & 100.00 & 100.00 & 100.00 & 100.00 \\
\hline IrCiliman & 100.00 & 100.00 & 100.00 & 100.00 & 99.00 & 7.71 & 100.00 & 99.00 & 100.00 & 100.00 & 100.00 & 100.00 \\
\hline IrCitiis & 100.00 & 100.00 & 100.00 & 17.12 & - & 45.56 & 100.00 & 100.00 & 100.00 & 100.00 & 100.00 & 100.00 \\
\hline Ir_diDASCipanggelangan & 100.00 & 98.29 & 100.00 & 10.76 & 3.67 & 23.58 & 100.00 & 57.81 & 100.00 & 100.00 & 100.00 & 100.00 \\
\hline Ir_di_Cimanyangray & - & - & - & - & - & - & 100.00 & - & - & - & - & - \\
\hline KEK Tanjung Lesung & 100.00 & 100.00 & 100.00 & 100.00 & 100.00 & 100.00 & 100.00 & 100.00 & 100.00 & 100.00 & 100.00 & 100.00 \\
\hline zzDICilimanExp & 100.00 & 100.00 & 100.00 & 0.18 & 0.03 & 0.03 & 100.00 & 99.58 & 100.00 & 100.00 & 100.00 & 100.00 \\
\hline
\end{tabular}

Sumber : Hasil analisis, 2018

\section{d) Kondisi dengan adanya Bendungan 3 di Sungai Ciliman}

Simulasi dengan WEAP ini merupakan simulasi terhadap kondisi dengan adanya bendungan $3 \mathrm{di}$ Sungai Ciliman. Tujuan simulasi ini untuk mengetahui pengaruh adanya bendungan 3 terhadap pemenuhan kebutuhan air baku di semua Kecamatan di DAS Ciliman dan irigasi serta mengkaji potensi untuk pemenuhan KEK Tanjung Lesung dan Bandara Panimbang dari Sungai Ciliman. Urutan prioritas yaitu untuk prioritas 1 adalah irigasi irigasi citiis, irigasi cipanggelangan, irigasi cibodas, irigasi cimanyangray, irigasi cinangkaruka, irigasi cilimus, dan irigasi cibulakan. Prioritas kedua adalah air baku. Prioritas ketiga adalah air baku sukaresmi, air baku panimbang, irigasi pompa kramatjaya, bandara dan KEK tanjung lesung. Prioritas keempat adalah industri munjul dan prioritas kelima adalah pengembangan irigasi ciliman seluas 2.200 hektar. Prioritas keenam adalah irigasi ciliman. 
e) Kondisi dengan adanya Bendungan 2 dan

Bendungan 3 di Sungai Ciliman

Simulasi dengan WEAP ini merupakan simulasi terhadap kondisi dengan adanya bendungan 2 dan bendungan 3 di Sungai Ciliman. Tujuan simulasi ini untuk mengetahui pengaruh adanya bendungan 2 dan bendungan 3 terhadap pemenuhan kebutuhan air baku di semua Kecamatan di DAS Ciliman dan irigasi serta mengkaji potensi untuk pemenuhan KEK Tanjung Lesung dan Bandara Panimbang dari Sungai Ciliman. Urutan prioritas yaitu untuk prioritas 1 adalah irigasi citiis, irigasi cipanggelangan, irigasi cibodas, irigasi cimanyangray, irigasi cinangkaruka, irigasi cilimus, dan irigasi cibulakan. Prioritas kedua adalah air baku. Prioritas ketiga adalah air baku sukaresmi, air baku panimbang, irigasi pompa kramatjaya, bandara dan KEK tanjung lesung. Prioritas keempat adalah industri munjul dan prioritas kelima adalah pengembangan irigasi ciliman seluas 3.200 hektar. Prioritas keenam adalah irigasi ciliman.

Tabel 7. Persentase rata-rata pemenuhan kebutuhan air DAS Ciliman tahun 2016- 2036 Skenario Bendungan Ciliman (Alt 4)

\begin{tabular}{|c|c|c|c|c|c|c|c|c|c|c|c|c|}
\hline & Apr & Mei & Jun & Jul & Ags & Sep & Okt & Nov & Des & Jan & Feb & Mar \\
\hline ABAngsana & 100.00 & 100.00 & 100.00 & 100.00 & 100.00 & 100.00 & 100.00 & 100.00 & 100.00 & 100.00 & 100.00 & 100.00 \\
\hline ABBanjarsari & 100.00 & 100.00 & 100.00 & 100.00 & 100.00 & 100.00 & 100.00 & 100.00 & 100.00 & 100.00 & 100.00 & 100.00 \\
\hline ABCirinten & 100.00 & 100.00 & 100.00 & 100.00 & 8.73 & 100.00 & 100.00 & 100.00 & 100.00 & 100.00 & 100.00 & 100.00 \\
\hline ABGunungKencana & 100.00 & 100.00 & 100.00 & 100.00 & 100.00 & 100.00 & 100.00 & 100.00 & 100.00 & 100.00 & 100.00 & 100.00 \\
\hline ABMunjul & 100.00 & 100.00 & 100.00 & 100.00 & 100.00 & 100.00 & 100.00 & 100.00 & 100.00 & 100.00 & 100.00 & 100.00 \\
\hline ABSindangresmi & 100.00 & 100.00 & 100.00 & 100.00 & 100.00 & 100.00 & 100.00 & 100.00 & 100.00 & 100.00 & 100.00 & 100.00 \\
\hline ABSobang & 100.00 & 100.00 & 100.00 & 100.00 & 100.00 & 100.00 & 100.00 & 100.00 & 100.00 & 100.00 & 100.00 & 100.00 \\
\hline ABSukaresmi & 100.00 & 100.00 & 100.00 & 100.00 & 100.00 & 100.00 & 100.00 & 100.00 & 100.00 & 100.00 & 100.00 & 100.00 \\
\hline Bandara & 100.00 & 100.00 & 100.00 & 100.00 & 100.00 & 100.00 & 100.00 & 100.00 & 100.00 & 100.00 & 100.00 & 100.00 \\
\hline DICinangkaruka & 100.00 & 100.00 & 100.00 & 100.00 & 37.15 & 100.00 & 100.00 & 100.00 & 100.00 & 100.00 & 100.00 & 100.00 \\
\hline DICibodas & 100.00 & 100.00 & 100.00 & 100.00 & 46.11 & 100.00 & 100.00 & 100.00 & 100.00 & 100.00 & 100.00 & 100.00 \\
\hline DICibulakan & 100.00 & 100.00 & 100.00 & 100.00 & 100.00 & 100.00 & 100.00 & 100.00 & 100.00 & 100.00 & 100.00 & 100.00 \\
\hline DI_Cilimus & 100.00 & 100.00 & 100.00 & 100.00 & 100.00 & 100.00 & 100.00 & 100.00 & 100.00 & 100.00 & 100.00 & 100.00 \\
\hline IndustriMunjul & 100.00 & 100.00 & 100.00 & 100.00 & 100.00 & 100.00 & 100.00 & 100.00 & 100.00 & 100.00 & 100.00 & 100.00 \\
\hline IrCiliman & 100.00 & 100.00 & 100.00 & 100.00 & 99.00 & 7.06 & 100.00 & 99.00 & 100.00 & 100.00 & 100.00 & 100.00 \\
\hline IrCitiis & 100.00 & 100.00 & 100.00 & 17.12 & - & 45.56 & 100.00 & 100.00 & 100.00 & 100.00 & 100.00 & 100.00 \\
\hline Ir_diDASCipanggelangan & 100.00 & 98.29 & 100.00 & 10.76 & 3.67 & 23.58 & 100.00 & 57.82 & 100.00 & 100.00 & 100.00 & 100.00 \\
\hline Ir_di_Cimanyangray & 100.00 & 100.00 & 100.00 & 83.97 & 9.21 & 62.01 & 100.00 & 100.00 & 100.00 & 100.00 & 100.00 & 100.00 \\
\hline KEK Tanjung Lesung & 100.00 & 100.00 & 100.00 & 100.00 & 100.00 & 100.00 & 100.00 & 100.00 & 100.00 & 100.00 & 100.00 & 100.00 \\
\hline zzDICilimanExp & 100.00 & 100.00 & 100.00 & 0.11 & 0.02 & 0.02 & 100.00 & 100.00 & 100.00 & 100.00 & 100.00 & 100.00 \\
\hline
\end{tabular}

Sumber : Hasil analisis, 2018

\section{Kesimpulan}

Dari hasil simulasi Skenario eksisting dapat disimpulkan beberapa hal, sebagai berikut:

a. Diperlukan pembangunan bendungan untuk memenuhi kebutuhan air baku menunjang ketahanan air dan ketahanan pangan

b. Berdasarkan analisis WEAP, alternatif terbaik dalam scenario pemenuhan kebutuhan air baku pada DAS Ciliman, yaitu skenario 5 dengan pengembangan lahan pertanian sebesar 3.200 hektar dan potensi pembangkit tenaga listrik rata-rata sebesar 0,97 MW per tahun.

c. Kebutuhan air pada DAS Ciliman untuk air baku masyarakat, KEK Tanjung Lesung, Bandara, industri, dan kebutuhan irigasi Ciliman hingga akhir tahun proyeksi (2036) terpenuhi 100\%, namun pada pengembangan perluasan sawah pada Bulan Juli - September, tetap terjadi defisit.

\section{DAFTAR PUSTAKA}

Badan Lingkungan Hidup Daerah Provinsi Banten. 2015. Profil Ekosistem DAS Ciliman.
Bai X. Imura H. 2001. Towards Sustainable Urban Water Resource Management : A Case Study in Tianjin, China. Sustainable Development Feb 2001 9, 1; ABI/INFORM Global pg. 24. John Wiley \& Sons, Ltd and ERP Environment.

Daniel EB, Camp JV, LeBoeuf JE, Penrod JR, Dobbins JP, Abkowitz MD. 2011. Watershed modelling and its applications: A state-of-theart review. Open Hydrol. J. 5:26-50.

Dinas Pekerjaan Umum dan Penataan Ruang. 2017. Pra FS Pembangunan Multipurpose DAM pada DAS Ciliman.

Dinas Pekerjaan Umum dan Penataan Ruang. 2018. FS Pembangunan Multipurpose DAM pada DAS Ciliman

Dinas Sumber Daya Air dan Permukiman Provinsi Banten. 2013. Pola Pengelolaan Sumber Daya Air Wilayah Sungai Ciliman-Cibungur.

Dinas Sumber Daya Air dan Permukiman Provinsi Banten. 2013. Pola Pengelolaan Sumber Daya Air Wilayah Sungai Ciliman-Cibungur.

Dinas Sumber Daya Air dan Permukiman Provinsi Banten. 2015. Studi Komprehensif Pengendalian Daya Rusak Air Pada DAS Ciliman.

Dinas Sumber Daya Air dan Permukiman. 2014. DED Penyediaan Air Baku Kawasan Tanjung Lesung.

Dinas Sumber Daya Air dan Permukiman. 2016. Penyusunan Perencanaan dan Evaluasi Alokasi Air Pada DAS Ciliman. 
Direktorat Jendral Cipta Karya Kementerian PUPR. 2016. Perencanaan Pengembangan SPAM Mendukung Kawasan Strategis Pariwisata Nasional Wilayah Barat.Hatmoko, W., Triweko, RW. 2011. Pengelolaan Alokasi Air pada Wilayah Sungai. Bandung : Pusat Penelitian dan Pengembangan Sumber Daya Air.

Direktorat Jendral Sumber Daya Air. 2011. Standar Perencanaan Irigasi. Jakarta: Direktorat Jendral Sumber Daya Air.

Hatmoko W Radhika Amirwandi S 2012 Neraca Ketersediaan dan Kebutuhan Air pada Wilayah Sungai di Indonesia (Bandung : Pusat Penelitian dan Pengembangan Sumber Daya Air)

Hussein, AH., 2015. Modelling Water Resource System for Effective Water Allocation of Juba Basin in Southern Somalia. Mekelle University Institute of Water and Environment. Mekelle, Ethiopia.
Pirie, RL., de Loe, RC., Kreutzwiser, R. 2004. Drought planning and water allocation : an assesment of local capacity in Minnesota. Journal of Environmental Management 73 (2004) 25-38

Putuhena JD. 2013. Model Dinamik Pengelolaan Daerah Aliran Sungai (watershed) Dalam Upaya Penyediaan Air Yang Berkelanjutan di Semenanjung Leitimor Pulau Ambon. Disertasi. Institut Pertanian Bogor.

Sieber, MS and Purkey, D., 2015. WEAP Tutorial. USA : Stockholm Environment Institute

Sieber, MS and Purkey, D., 2015. WEAP User Guide USA : Stockholm Environment Institute

Surya, RA. 2015. Kebijakan Pengelolaan Sumberdaya Alam Untuk Penyediaan Air Baku Berkelanjutan Di Tingkat Kabupaten (Studi Kasus Kabupaten Konawe Provinsi Sulawesi Tenggara). Disertasi. Institut Pertanian Bogor 